This item was submitted to Loughborough's Research Repository by the author.

Items in Figshare are protected by copyright, with all rights reserved, unless otherwise indicated.

\title{
A review of the state of the art in tools and techniques used to evaluate remanufacturing feasibility
}

PLEASE CITE THE PUBLISHED VERSION

http://dx.doi.org/10.1016/j.jclepro.2014.06.014

\section{PUBLISHER}

(C) Elsevier Ltd.

\section{VERSION}

AM (Accepted Manuscript)

\section{PUBLISHER STATEMENT}

This work is made available according to the conditions of the Creative Commons Attribution-NonCommercialNoDerivatives 4.0 International (CC BY-NC-ND 4.0) licence. Full details of this licence are available at: https://creativecommons.org/licenses/by-nc-nd/4.0/

\section{LICENCE}

CC BY-NC-ND 4.0

\section{REPOSITORY RECORD}

Goodall, Paul A., Emma L. Rosamond, and Jennifer A. Harding. 2019. "A Review of the State of the Art in Tools and Techniques Used to Evaluate Remanufacturing Feasibility”. figshare. https://hdl.handle.net/2134/17026. 


\section{A review of the state of the art in tools and techniques used to evaluate remanufacturing feasibility}

Paul Goodall*, Emma Rosamond, Jenifer Harding

Wolfson School of Mechanical and Manufacturing Engineering, Loughborough University, Loughborough, LE11 3TU, UK

*Corresponding Author Tel. +4401509 227671

Email Address: $\underline{\text { P.A.Goodall@lboro.ac.uk }}$

Postal Address: Wolfson School of Mechanical and Manufacturing Engineering, Loughborough University, Loughborough, LE11 3TU, UK 


\section{Abstract}

Remanufacturing often seems a sensible approach for companies looking to adopt sustainable business plans to achieve long term success. However, remanufacturing must not be treated as a panacea for achieving a sustainable business, as issues such as market demand, product design, end of life condition and information uncertainty can affect the success of a remanufacturing endeavour. Businesses therefore need to carefully assess the feasibility of adopting remanufacturing before committing to a particular activity or strategy. To aid this decision process, a number of tools and techniques have been published by academics. However, there is currently not a formal review and comparison of these tools and how they relate to the decision process.

The main research objective of this study has therefore been to identify tools and methods which have been developed within academia to support the decision process of assessing and evaluating the viability of conducting remanufacturing, and evaluate how they have met the requirements of the decision stage. This has been achieved by conducting a content analysis. Three bibliographic databases were searched (Compendex, Web of Science and Scopus) using a structured keyword search to identify relevant literature. The identified tools were then split into 6 categories based upon the specific decision stages and applications, then evaluated against a set of key criteria which are, the decision factors (economic, environmental, social) and the inclusion of uncertainty. The key finding of this study has been that although decision factors are generally well covered, operational tools and the use of uncertainty are often neglected.

Keywords; Remanufacturing, Decision Making, Sustainability

\section{Introduction}

Interest in End of Life (EoL) activities within industry and academia is increasing as financial and legislative pressures are forcing businesses to pursue different methods of increasing materials efficiency and reducing waste. One EoL activity that has drawn particular interest is remanufacturing. Remanufacturing is the process of returning used, damaged or discarded products up to the quality standards of new products and with an equivalent warranty (Ijomah, 2009;Thierry et al., 1995). Remanufacturing differs from other forms of reuse, such as repair or reconditioning, due to the higher quality to which a product is returned.

Although remanufacturing in itself is not a new concept, with accounts dating back to the second world war (Hatcher et al., 2011) , it was not until early publications by Lund (Lund, 1984;Lund, 1985) that remanufacturing was discussed as a research topic within the academic community, with the connotations of sustainable business practice. Remanufacturing not only reclaims the material content, but also retains the embodied energy used to manufacture the original product from the raw materials (King et al., 2006). This can potentially reduce the cost of producing products whilst also minimising the environmental impact by reducing resource consumption and waste.

Although remanufacturing may seem attractive to businesses, it must not be treated as a panacea for generating low cost, low environmental impact and high quality products. A number of factors can affect the success of a remanufacturing endeavour such as the demand, design and the condition of returned products. With remanufacturing requiring a somewhat larger investment than other EoL options such as recycling, it is therefore important that decision makers carefully assess its 
viability at all levels of a business, from strategic planning, right through to the operational stage. This decision making process can be further hindered by the relatively high level of uncertainty present within a remanufacturing system.

To aid this decision process a number of academics have developed methods and tools designed to assist decision makers when tackling this task. These tools have been designed to be used at particular stages within the business (such as strategic planning or operational), consider certain decision factors and sometimes allow for uncertainty to be expressed. However, there currently lacks a comprehensive review of these specific tools, evaluating them against requirements of the decision making phase. The research objective of this paper is therefore to answer the following question; What tools and methods have been developed within academia to support the decision process of assessing and evaluating the viability of conducting remanufacturing, and how have they met the requirements of the decision stage?

To achieve this objective a content analysis is conducted. The tools found are categorised by the type of decision supported within the business, and they are then evaluated against the decision factors they support and the inclusion of uncertainty.

The paper is structured as follows (shown in Figure 1). First, a background decision making framework of the remanufacturing assessment process is conducted, with the aim of highlighting the requirements of this decision. This has been split into five sub sections which discuss the methodology used to develop the framework, the decision factors, the different decision stages, the challenges of decision making for remanufacturing and the findings. This background framework aims to provide context for the later evaluation of the tools in the content analysis. Next, the methodology of the content analysis of tools and methods is shown. Results of the review are then presented followed by a discussion of the results, using the earlier background summary as guidance. Finally, conclusions are drawn from the research and areas of future work are highlighted. 


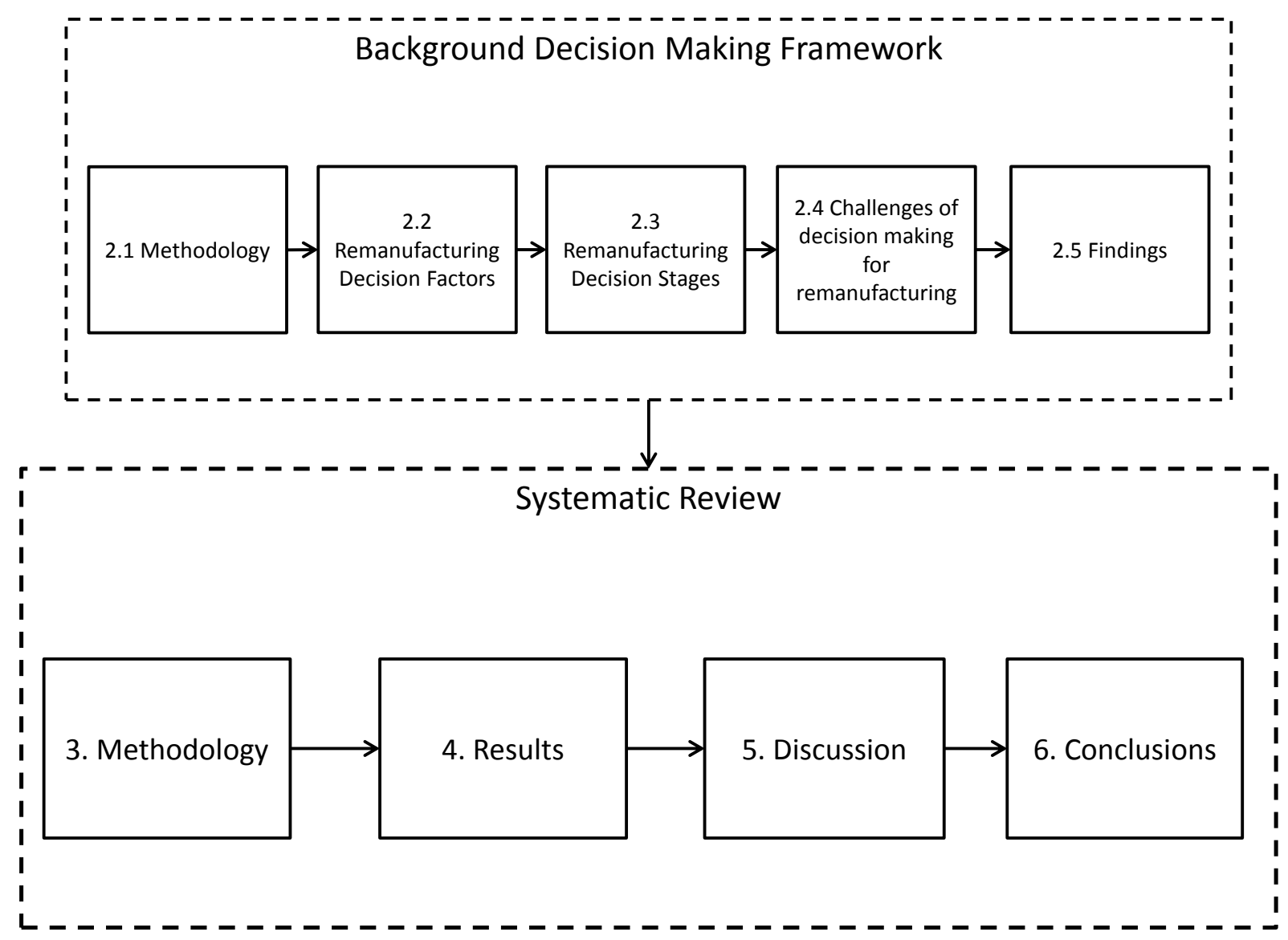

Figure 1 The research methodology

\section{Evaluating Remanufacturing Decision Making}

The purpose of this section is to understand the area of EoL decision making for remanufacturers, and create a framework for assessing the tools and methods later in this paper. With this in mind, the three specific aims that have been identified for this section are; to determine what are the factors that influence these decisions, to understand the context in which these decisions are made and to identify what are the challenges decision makers have within this area.

\subsection{Methodology}

In order to provide an understanding of EoL decision making within remanufacturing, a framework of the area is developed. The main source of data for this section relies on existing literature published in peer reviewed journals. The research is grounded in highly cited journal publications, shown in Table 1, and supplemented with additional relevant peer reviewed journal publications and findings from high level case studies, in order to develop and justify the framework.

Table 1 Highly cited journal publications within the area of remanufacturing decision making

\begin{tabular}{|l|l|l|l|}
\hline Article & Decision Category & $\begin{array}{l}\text { Total number of } \\
\text { Google Scholar } \\
\text { citations }\end{array}$ & Citations per year \\
\hline Thierry et al. (1995) & Strategic & 1043 & 54.9 \\
\hline Sarkis (2003) & Strategic & 619 & 61.9 \\
\hline Dowlatshahi (2005) & Strategic & 122 & 15.3 \\
\hline
\end{tabular}




\begin{tabular}{|l|l|l|l|}
\hline Seitz (2007) & Strategic and Tactical & 119 & 19.8 \\
\hline $\begin{array}{l}\text { Subramoniam et al. } \\
\text { (2009) }\end{array}$ & Strategic & 67 & 16.8 \\
\hline Östlin et al. (2009) & Strategic & 65 & 16.3 \\
\hline Gehin et al. (2008) & Tactical & 114 & 22.8 \\
\hline $\begin{array}{l}\text { Bras and Mclntosh } \\
\text { (1999) }\end{array}$ & Tactical & 107 & 7.6 \\
\hline Guide (2000) & Tactical and Operational & 533 & 41 \\
\hline ljomah et al. (2007) & Tactical and Operational & 68 & 13.6 \\
\hline
\end{tabular}

Five high level case studies have been used within this study. A diverse selection of remanufacturers were chosen (i.e. OEM, independent, high and low value, and high and low volume) to represent the different types of remanufacturers identified. Data was collected in the form of informal interviews and observations from visits to the remanufacturing facilities. Profiles of the case studies can be found in Table 2.

Table 2 Profiles of the remanufacturing businesses case studies

\begin{tabular}{|l|l|l|l|l|l|}
\hline Name & Business Scenario & Remanufacturer Type & Product & Interviewee & $\begin{array}{l}\text { Visit to } \\
\text { Remanufacturing } \\
\text { Facility }\end{array}$ \\
\hline Case 1 & $\begin{array}{l}\text { Product/Part } \\
\text { Service }\end{array}$ & $\begin{array}{l}\text { Independent Third } \\
\text { Party }\end{array}$ & $\begin{array}{l}\text { Wind Turbine } \\
\text { Gearbox }\end{array}$ & $\begin{array}{l}\text { Senior } \\
\text { Management, } \\
\text { Operational } \\
\text { Manager }\end{array}$ & Yes \\
\hline Case 2 & $\begin{array}{l}\text { Aftermarket Spare } \\
\text { Parts/ Warranty }\end{array}$ & $\begin{array}{l}\text { OEM and licenced } \\
\text { third party }\end{array}$ & Automotive Parts & $\begin{array}{l}\text { Factory } \\
\text { management }\end{array}$ & No \\
\hline Case 3 & $\begin{array}{l}\text { Aftermarket Spare } \\
\text { Parts/ Warranty }\end{array}$ & $\begin{array}{l}\text { OEM and licenced } \\
\text { third party }\end{array}$ & $\begin{array}{l}\text { Industrial } \\
\text { machine parts }\end{array}$ & $\begin{array}{l}\text { Factory } \\
\text { management }\end{array}$ & Yes \\
\hline Case 4 & $\begin{array}{l}\text { Whole Product/ } \\
\text { Aftermarket Spare } \\
\text { Parts }\end{array}$ & $\begin{array}{l}\text { Independent Third } \\
\text { Party }\end{array}$ & $\begin{array}{l}\text { Automotive } \\
\text { Lighting }\end{array}$ & Owner & Yes \\
\hline Case 5 & $\begin{array}{l}\text { Product/Part } \\
\text { Service }\end{array}$ & $\begin{array}{l}\text { OEM, licenced third } \\
\text { party, independent } \\
\text { third party }\end{array}$ & Gearboxes & Business Manager & Yes \\
\hline
\end{tabular}

The framework is presented in three sections to answer the specific aims outlined the beginning of section; Remanufacturing Decision Factors, Remanufacturing Decision Stages, and Challenges to Decision Making for Remanufactures.

With remanufacturing often being linked to sustainability (Mayyas et al., 2012;Rathore et al., 2011), the framework of the three pillars of sustainability which are economic, environmental and social, will be used to categorise the unique decision factors businesses should consider when assessing the feasibility of remanufacturing. Decision stages have been categorised based upon traditional managerial decisions which are strategic, tactical and operational phases.

\subsection{Remanufacturing Decision Factors}

\subsubsection{Economic}

The economic decision factors have been split into two categories; value and cost. The value section addresses factors that influence the value of remanufacturing to both the customer and the business conducting remanufacturing, whilst the costs section addresses factors that affect the cost of remanufacture. 
Value

In order to be a successful endeavour, remanufacturing must offer some value relative to other options or strategies. Dowlatshahi (2005) notes that ensuring the needs of the customer are met is of primary importance, before establishing a reverse logistics network to enable remanufacturing. Sarkis (2003) also highlights the importance of assessing the performance criteria of reverse logistics options such as cost, quality and time, relative to other strategies. Remanufacturing has been shown to be a valuable strategy within a number of business scenarios, shown in Table 3. Depending upon the business scenario, remanufacturing can potentially offer customer benefits through reduced cost and time and improved quality, compared to alternative strategies.

Table 3 Business scenarios in which remanufacturing takes place

\begin{tabular}{|l|l|}
\hline Business Scenario & Product Example \\
\hline Whole Product Remanufacture & Single use cameras (Matsumoto and Umeda, 2011) \\
\hline Aftermarket Spare Parts & Automotive spare parts (Subramoniam et al., 2009) \\
\hline Warranty (OEM or licenced third party) & Electronic game consoles (Walsh, 2010) \\
\hline Product/ Part Service & Wind Turbine Gearboxes (Case 1 and Case 5) \\
\hline Product Service System (PSS) & Photocopiers (Kerr and Ryan, 2001), Aero Engines (ljomah, 2009) \\
& \\
\hline
\end{tabular}

Economic savings within remanufacturing, relative to traditional manufacturing, are primarily attributed to reduced material and processing costs. These arise from the reuse of a product which enables both the material content and the embodied energy of the original manufacturing process to be retained (Thierry et al., 1995). However, it should be noted that remanufacturing also accrues additional costs which manufacturing will not incur. These costs occur in remanufacturing through the need of reverse logistics and additional processes such as disassembly and inspection (discussed further in the next section on Process Costs). Additionally, where manufacturing takes place in high volumes, processes can become more efficient by taking advantage of economies of scale.

Remanufacturing may struggle to compete with manufacturing on cost when it is conducted on this scale, as it tends to occur in smaller volumes and includes labour intensive process such as disassembly (Kerr and Ryan, 2001). When mass production of products and components ends, then the opportunity for remanufacturing occurs as seen in the automotive spare parts industry (Inderfurth and Mukherjee, 2008;Seitz, 2007).

If cores are available, then remanufacturing may be a faster way of replacing a product or component than with a newly manufactured one, particularly when normal production has ceased, no stock is available or when there is full capacity at the manufacturer's facility. Case 2 cited reduced lead times of producing remanufactured parts for the automotive aftermarket as one of the key drivers for remanufacture, particularly for rare items which are no longer mass produced and would therefore require custom manufacture. Reduced lead times is also an important factor within the wind energy business, as highlighted by Case 1 and Case 5, as downtime to replace components stops wind turbines generating power and thus revenue.

The quality of the goods produced by remanufacturing may also be higher than those of other EoL strategies such as repair, or refurbishment (Thierry et al., 1995). However, the perceived value of remanufactured goods tends to be less than those that have been newly manufactured. This perceived value gap is even greater within the Business-to-Customer (B2C) market opposed to the Business-to-Business (B2B) (Atasu et al., 2008). This is largely due to B2C products having a 
considerable fashion emphasis whereas B2B products are purchased predominantly for their functional attributes.

In order to exploit the benefits of remanufacturing, both a demand from the market and a supply of used cores is required. Product demand varies with time and is heavily linked to factors such as obsolescence (Ayres et al., 1997). This is influenced by factors such as advances in technology (Guide, 2000) and fashion (ljomah et al., 2007). The complication with remanufacturing is that the product demand can only be satisfied if returned product cores are available. Where the demand and availability of cores overlap, the opportunity for remanufacture to be of value exists. Sarkis (2003) highlights the importance of the product life cycle phase within strategic decision making. For further information see Östlin (2009), who provides a detailed explanation of this area.

There are also indirect consequences of remanufacturing which business should also consider within their decision. Cannibalisation of new product sales is a concern for many OEMs (Atasu et al., 2008;Guide Jr and Van Wassenhove, 2009). Many OEMs fear that a percentage of their new product sales will become lost as a result of remanufacturing. Brand erosion and the protection of intellectual property is a concern for OEMs whose products may be remanufactured by third parties (Subramoniam et al., 2010). When remanufacturing is conducted by third parties, the OEMs have no control over the level of quality that the work is conducted to. However, as the product still bears the OEM's name and identity, poor quality remanufacturing may still be linked to them, thus potentially eroding their brand image (Seitz, 2007).

\section{Economic Costs}

It is important for decision makers to assess the economic implications of remanufacturing. Understanding the factors that contribute to the financial cost of operating a remanufacturing business can allow decision makers to assess the suitability of remanufacturing at strategic, tactical and operational levels.

Making use of current resources can be an important way of reducing the overall cost of remanufacturing (Dowlatshahi, 2005). Having to invest in additional facilities, equipment, infrastructure and skill base can result in a higher costs, which may lead to remanufacturing becoming an unattractive option.

The cost of remanufacturing an individual product can be attributed to the sub processes and activities which are undertaken within them. For remanufacturing a list of generic processes are well defined. These are acquisition, logistics, disassembly, cleaning, storage, rework, assembly and testing (Sundin and Bras, 2005), each of which can be further broken down into generic costs including labour, materials and overheads. These process and activity costs are by no means fixed, and can vary significantly between similar product types for a number of reasons including the physical EoL condition of the returned product, product design, and overall process efficiency (affected by batch size and inventory control) as highlighted in Figure 2. 


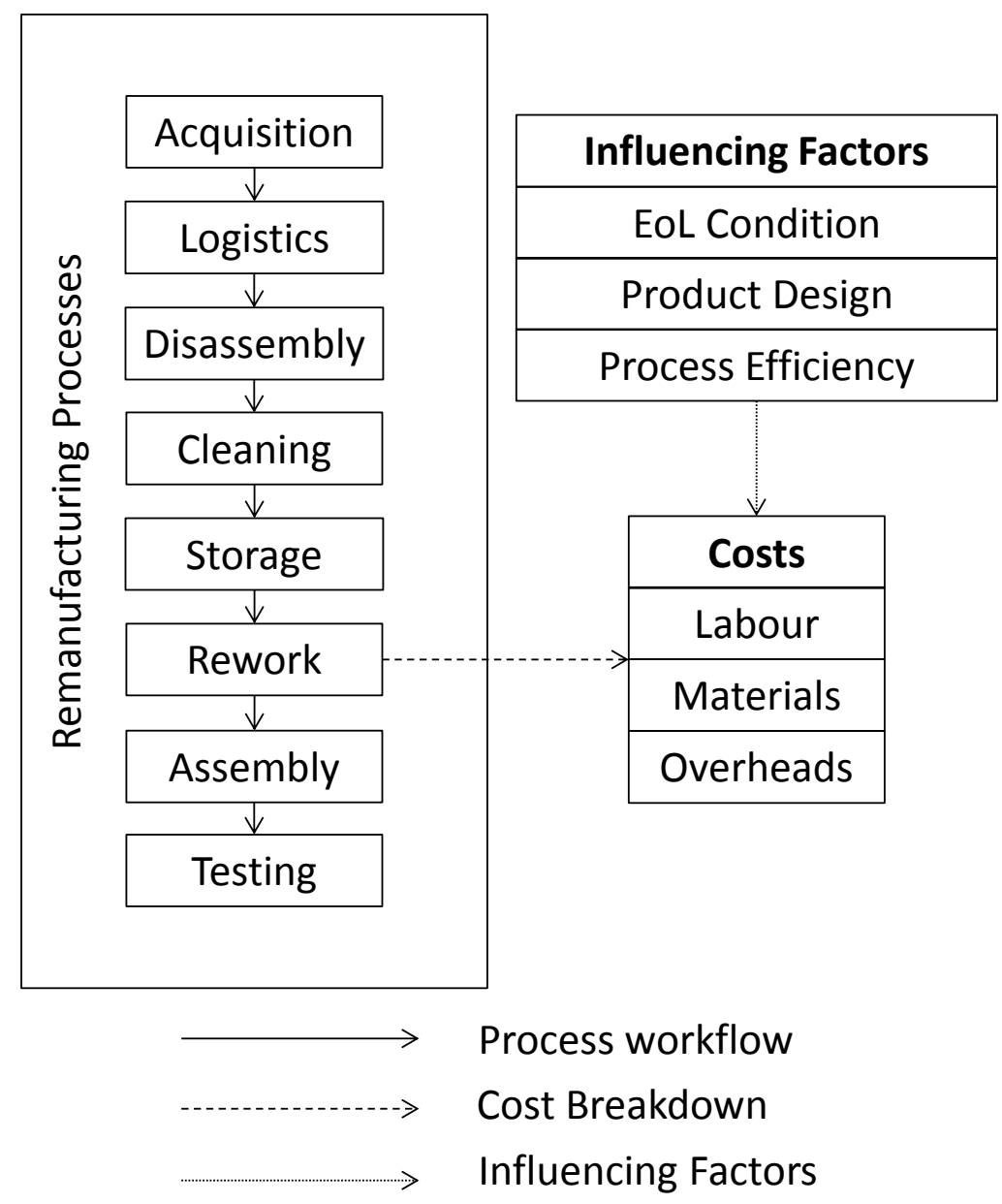

Figure 2 Break down of the generic remanufacture process with costs and the factors that affect these shown for the rework stage

The difference between the condition of the returned product core and the required final quality level of remanufacturing has a significant influence in the overall cost (Jun et al., 2007). Higher wear and damage may require more expensive process techniques in order to return a component to the required quality level (Östlin et al., 2009). For example worn gears must be either reworked or replaced in order to remanufacture the entire gearbox. Light wear can require surface finishing, whilst heavy wear entails grinding and if damage is too severe then replacement is required (Michaud et al., 2011).

The product design can have significant impact on the cost of the remanufacturing processes. Sundin and Bras (2005) link product properties such as ease of identification, verification, access, handling, separation, securing, alignment, stacking and wear resistance with the generic remanufacturing processes shown in Figure 2. For example, the ease of separation can be affected by the joining method of internal components. Difficultly in disassembly can increase the process time, number of separating tools and probability of damage to the product, thus increasing the total cost (Sundin and Lindahl, 2008). Design for remanufacture aims to improve the potential for a product to be remanufactured and is discussed in greater detail by Hatcher et al. (2011).

When remanufacturing factories are not operating at optimum levels inefficiencies will occur, leading to added costs. This can stem from issues such as bottle necks within the production system, 
capacity constraints and overstock or under stock of inventory resources. A number of tools have been developed to assist remanufacturers with optimising these production planning and inventory control issues and are discussed in greater depth by llgin and Gupta (2010).

\subsubsection{Environmental}

Remanufacturing activities are becoming more and more attractive due to the benign environmental impacts associated with them (King et al., 2006). Proactive businesses may see remanufacturing as a method of greening their business activities, whilst environmental legislation may force businesses to consider the environmental effects of their actions.

By conducting remanufacturing, products which may else have been sent to landfill, can be given extended life cycles, such as that found within Case 3 . This can potentially reduce the need to manufacture products from new, thus saving precious natural resources. The remanufacture of a starter motor has the potential of saving nine times the quantity of material and use seven times less energy than to manufacture from new (Matsumoto and Umeda, 2011), whilst the process of engine remanufacture has been quoted as using $83 \%$ less energy than a newly manufactured equivalent (Smith and Keoleian, 2004). Remanufacturing is also seen as environmentally preferable to other EoL options such as recycling as not only is the material preserved but also the 'embodied energy' from the initial manufacturing processes. However when assessing the environmental impacts of remanufacturing the savings gained over manufacturing from new must be compared to the potential impact in prolonging products where technologies have been superseded with more energy efficient means. In many cases a product's environmental impact can be much greater during the use phase of their life than during the manufacturing stage which is an important factor to consider when evaluating the environmental impact of remanufacturing (Gutowski et al., 2011). Many remanufactured products also do not have to conform to the latest environmental regulation policy, only that of which they were required to at the time of their original manufacturer, which is the case for Case 3.

Although governmental directives and legislation have often been attributed as an incentive to conduct remanufacturing activities (Barker and King, 2006;Guide, 2000), the weight of this assumption has been questioned by some researchers within literature. The End of Life Vehicles (ELV) directive designed to reduce waste within the automotive industry has been criticised by Gerrard \& Kandlikar (2007) in that it does not encourage higher forms of waste management hierarchy such as remanufacturing, instead promoting recycling and energy recovery. Seitz (2007) also questions the effect of ELV as a driver for engine OEM's who conduct remanufacturing and, based upon industrial interviews concluded that little evidence could be attributed to the ELV directive being directly attributed to the decision to remanufacture within this sector.

\subsubsection{Social}

Dyllick and Hockerts (2002) split the social aspect of sustainability into two categories; the human aspect and societal aspect. The human aspect concerns factors such as skill, motivation and loyalty of both employees and business partners, whilst the societal aspect concerns the communities in which businesses conduct their activities. Within remanufacturing literature several factors which can affect decision making have been discussed that fit into this category. 
From a consumer perspective remanufacturing can offer low cost alternatives to many high quality products. There is also the opportunity of additional job creation as at present remanufacturing tends to be a labour intensive task due to processes such as disassembly being required (Parkinson and Thompson, 2003). However, remanufacturing may allow old technology, which has been superseded by products boasting improved safety, to remain in use and available in the market place (e.g. motor vehicles). Companies must also consider the safety aspects of remanufacturing processes such as potential risks within the disassembly process (e.g. spring loaded parts) and the potential interaction with hazardous substances (chemicals, oils etc.) for both employees and local residents (Presley et al., 2007).

Remanufacturers must ensure that the work they conduct meets particular quality and safety standards (Dowlatshahi, 2005). Case 5 indicated that the electrical equipment being remanufactured must conform to particular electrical standards before being sold. It is important therefore, that decision makers assess the viability of meeting these standards when making the decision as whether to remanufacture.

A key feature of remanufacturing is the level of customer satisfaction it can offer particularly within the aftermarket, which can also be included within the social aspect of the sustainability (Hubbard, 2009). The option of remanufactured parts and components can reduce the cost to the customer whilst prolonging the life of the overall product in which the remanufactured component is used. Economically it may be more desirable for the business to sell new products at a higher cost however by sharing the benefits of lower cost, high quality products that remanufacturing can offer can lead to strong long lasting customer relations desired by a sustainably minded business. Seitz (Seitz, 2007) found this to be one of the motives for business to conduct remanufacturing.

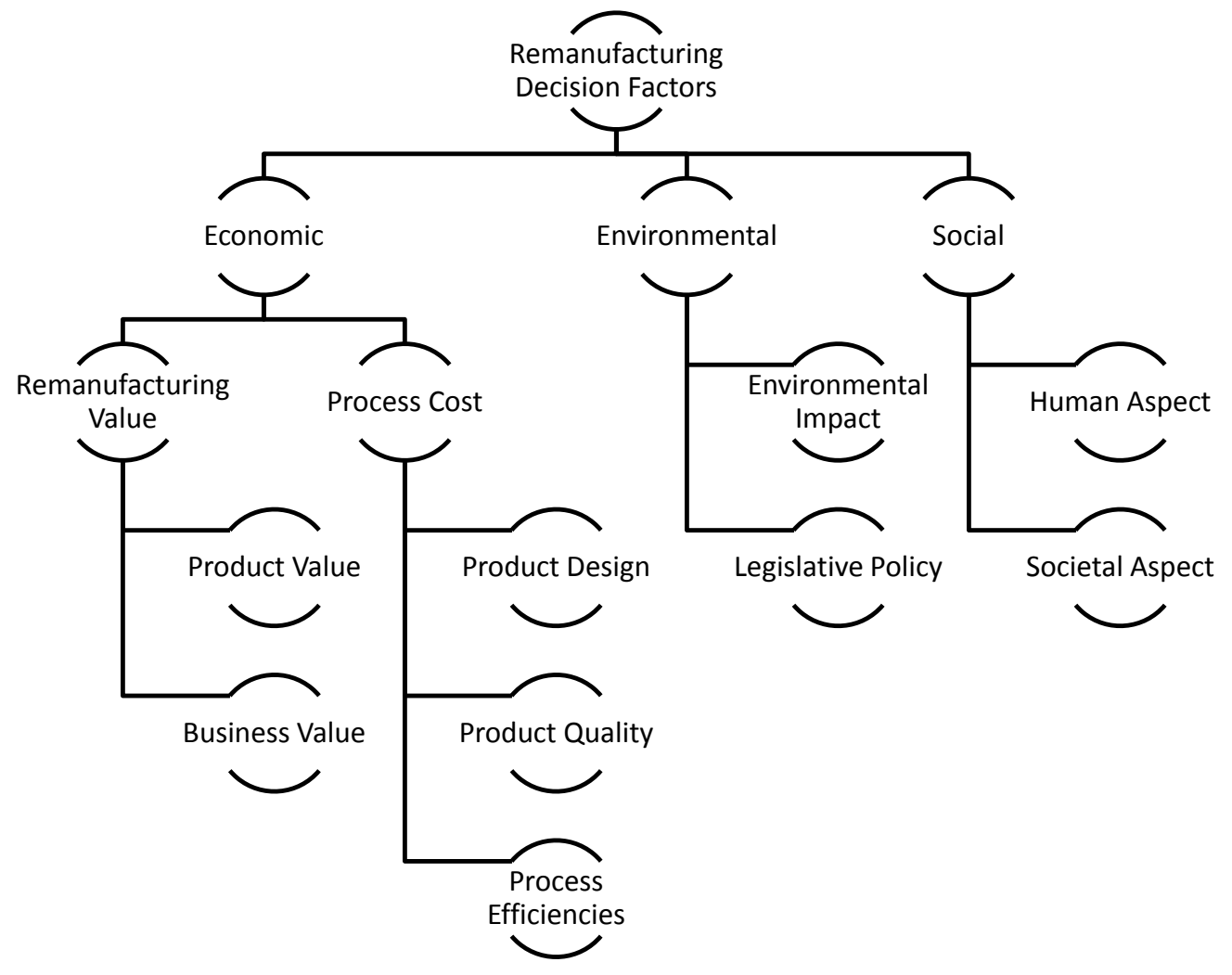

Figure 3 An overview of the remanufacturing decision factors, adapted from Dunmade (2004) 


\subsection{Remanufacturing Decision Stages}

\section{Strategic}

Strategic decisions are made at a high level and are aimed to shape the long term future of a business. Within the context of EoL assessment, strategic decisions assess whether remanufacturing is a suitable strategy for the business. This decision is usually taken prior to the establishment of remanufacturing activities and additionally at periodic stages to review whether it is having the desired effect on the business. Scenarios in which remanufacturing have been successfully incorporated into a business are shown within Table 3.

OEM's may additionally make strategic decisions regarding EoL of products at the conceptual product design phase, particularly when they have invested interests such as found within the Product Service System (PSS) business scenario. If remanufacturing is deemed a preferred option for a product's EoL, then steps can be taken to enable specific features constructive to remanufacture to be designed in (Gehin et al., 2008).

Strategic decisions require elements of all of the decision factors discussed within the previous section, although the level of detail in which these are addressed will be less than that of tactical and operational due to their long term nature.

\section{Tactical}

Tactical decisions tend to be focused toward the medium term, with the aim of providing a method for implementing the chosen strategy. Within the context of assessing remanufacturing as an EoL option the tactical issue involves the planning of the remanufacturing business, more specifically determining which products are to be considered for remanufacture.

The tactical decision of which products to remanufacture is made based upon specific product types and models rather than particular product instances. Most remanufacturers will receive a range of cores consisting of different product models and manufacturers (Guide, 2000). Performing a full detailed analysis of whether to remanufacture each time a product is received will require a large amount of resource, adding to the overall cost of remanufacture. For low cost and high volume remanufacturing this level of analysis for each product instance can be expensive and time consuming, therefore it can be useful to develop general rules and heuristics at a tactical level to guide operational decisions. In the case studies analysed, this type of decision occurred within all of the businesses, although the degree to which this occurs varies. Case 3 conducts a detailed analysis before a product model is accepted for remanufacture within the plant. For remanufacturers of products of higher value and lower quantities the tactical assessment of products is conducted on a per product basis. Case 1 estimates cost and time required to remanufacture a product for a customer to determine if they would like to proceed.

\section{Operational}

Operational decisions are those which are encountered on a day to day basis. Within the context of assessing remanufacturability, this type of decision mostly focuses upon assessing individual products and components. Within a remanufacturing facility this decision will be built into the remanufacturing process through product inspections. The aim of an inspection is to filter out 
products and components which are not suitable for remanufacture, thus ensuring that resources are not wasted through unnecessary processing. These inspection decisions can occur at various points during the remanufacturing process with varying degrees of information available at each stage. For example an initial inspection can be conducted before the product arrives at the remanufacturing facility, using Middle of Life (MoL) information (Case 1, 2 and 5). This 'virtual' inspection can save upon logistical costs, although requires sufficient infrastructure to be available, such as embedded sensors and conditional monitoring networks, in order to collect and analyse the information. This type of inspection has been discussed within literature by several authors (Jun et al., 2007; Klausner et al., 1998). Within the interviews, some of the businesses were beginning to utilise this facility, although none had fully integrated it into their remanufacturing process. Visual inspections are used widely as a fast and cheap method of assessing products at the early stage of remanufacture. Operators are trained to identify particular faults or use their experience to assess products' remanufacturability. As the remanufacturing process progresses more specific inspections are carried out, such as metrological measurements and physical tests.

Table 4 Summary of the decision stages for assessing remanufacturing feasibility

\begin{tabular}{|l|l|l|l|}
\hline Decision Stage & Key Purpose & $\begin{array}{l}\text { Information contained } \\
\text { within product description }\end{array}$ & Potential Users \\
\hline Strategic & $\begin{array}{l}\text { Provide early feasibility } \\
\text { analysis of adopting } \\
\text { remanufacturing within a } \\
\text { business strategy }\end{array}$ & General Product Type & $\begin{array}{l}\text { High level/senior } \\
\text { management/ middle } \\
\text { management }\end{array}$ \\
\hline Tactical & $\begin{array}{l}\text { Evaluate a particular } \\
\text { product design for } \\
\text { remanufacture. Can either } \\
\text { be used in the product } \\
\text { design phase, or in the } \\
\text { operational planning phase. }\end{array}$ & $\begin{array}{l}\text { Specific Model, product } \\
\text { structure and BoM maybe } \\
\text { included }\end{array}$ & $\begin{array}{l}\text { Middle management/ } \\
\text { operational } \\
\text { management/ design } \\
\text { engineers }\end{array}$ \\
\hline Operational & $\begin{array}{l}\text { Evaluate a specific product } \\
\text { for remanufacture. Can } \\
\text { occur remotely using MoL } \\
\text { information or during } \\
\text { inspections at the } \\
\text { remanufacturing facility. }\end{array}$ & $\begin{array}{l}\text { Detailed product structure } \\
\text { including information } \\
\text { related to condition of the } \\
\text { product. Additional process } \\
\text { information may also be } \\
\text { provided such as inventory } \\
\text { levels and factory capacity. }\end{array}$ & $\begin{array}{l}\text { Middle management/ } \\
\text { operational } \\
\text { management/ }\end{array}$ \\
\hline
\end{tabular}

\subsection{Challenges of decision making for remanufacturing}

The key factor which complicates remanufacturing decision making relative to traditional forward manufacturing, is the high level of uncertainty associated with the return product cores. This uncertainty stems from the lack of information flow between early life cycle phases (in particular the use phase) and the remanufacturer. There are three main uncertainties present in remanufacturing systems; the condition (Galbreth and Blackburn, 2010;Guide, 2000), the design and physical structure (ljomah, 2009), and the timings and quantities of product returns(de Brito and van der Laan, 2009;Ferrer and Ketzenberg, 2004; Inderfurth, 2005). 
The condition of products being evaluated for remanufacturing will vary considerably due to the uncertain nature of the use phase of their life (Guide, 2000), where the operational environment, users, tasks and time will all vary from product to product. The design and physical structure may vary throughout the life of a product with upgrades and modification potentially occurring. If the original product designs are not available to the remanufacturer then it further adds to the uncertainty at the remanufacturing stage. The timing and quantity of product returns are also likely to be unknown as it is usually the user that determines when it is to be relinquished, not the remanufacturer.

The effects of these uncertainties are strongly felt within the remanufacturing environment. Strategic decisions, which are already required to deal with uncertain information due to their long term nature, are further complicated with these specific uncertainties. Östlin (2009) discusses how these uncertain factors can hinder the ability to anticipate and exploit product life cycle trends, such as timing and quantities of product returns. Uncertainties regarding the condition and product structure can lead to uncertain process routing, as the full set of activities required to complete remanufacture will not be known (Guide, 2000). This can make it difficult to predict performance metrics such as cost, time and environmental impact of remanufacturing. Unknown timings and quantities can cause problems for production planning and inventory control, which can reduce the overall efficiency of the remanufacturing plant through process bottle necks, unfavourable lot sizing and carrying of unnecessary inventory. All of these uncertainties can therefore make it difficult to predict metrics, such as remanufacturing cost, which are used within remanufacturing decision making. Understanding these uncertainties and their impacts are therefore important when assessing the risk associated with a decision.

It should be noted however that the level of uncertainty within a remanufacturing system can vary greatly depending upon the solutions which may have been implemented to reduce it. The relationship that the remanufacturer has with the OEM may dictate the information available from the manufacturing stage to aid with remanufacturing, such as the product design, manufacturing dates and quality test results. The amount of information feedback throughout a products' useful life will also significantly affect the uncertainty at the remanufacturing stage. Regular contact with the product, through service and scheduled maintenance, can enable data to be recorded throughout the product lifecycle. Additionally the use of technologies such as embedded sensors can enable monitoring of a products' condition during the use phase of its life cycle, thus allowing real time diagnostics to take place (Ilgin and Gupta, 2011;Jun et al., 2007). This can enable remanufacturers to know the condition of the product prior to its arrival for remanufacture and also when it may be returned, reducing uncertainty within these areas. Contracts with suppliers and incentives to return cores can also be used to help reduce these uncertainties (ljohmah, 2009).

Table 5 Identifying the sources, effects and solutions to uncertainty within remanufacturing

\begin{tabular}{|l|l|l|l|l|}
\hline \multirow{2}{*}{ Uncertainty Source } & \multicolumn{3}{|c|}{ Effect on decision making } & Operational \\
\cline { 2 - 5 } & Strategic & Tactical & $\begin{array}{l}\text { Measuring and } \\
\text { quantifying core } \\
\text { quality accurately }\end{array}$ & $\begin{array}{l}\text { Multiple inspection stages, } \\
\text { obtaining MoL product } \\
\text { information, }\end{array}$ \\
\cline { 1 - 3 } & $\begin{array}{l}\text { Returned core condition } \\
\text { identifying the effect } \\
\text { of long term decision } \\
\text { factors }\end{array}$ & $\begin{array}{l}\text { Assessing the impact of } \\
\text { uncertainties upon } \\
\text { performance metrics such } \\
\text { as cost, time, quality and } \\
\text { environmental impact }\end{array}$ & $\begin{array}{l}\text { Determining the } \\
\text { evaluation criteria }\end{array}$ & $\begin{array}{l}\text { Links to OEM to obtain } \\
\text { product information, } \\
\text { effectively store product } \\
\text { information obtained from } \\
\text { experience }\end{array}$ \\
\end{tabular}


Timings and quantities of returns
Contracts with core suppliers, offer cash back for cores

\subsection{Findings}

Based upon the inspection of key literature and the verification of industrial case studies, a framework of the key factors required for assessing the feasibility of remanufacturing have been identified and presented. The key factors which affect the decision have been highlighted and categorised using the three pillars of sustainability and are summarised in Figure 3. Decision making can be split into three key areas; strategic, tactical and operational decisions. The key factors are applicable at each of the decision levels, however the detail of the information required at each stage will vary. Finally a major factor which complicates remanufacturing decision making is the inherent uncertainty surrounding the product lifecycle. This is shown to be particularly problematic within the tactical and operational phases of decision making, when little information accompanies the product to remanufacturing. 


\section{Review Methodology}

Within the introduction, the research question of this study is presented; What tools and methods have been developed within academia to support the decision process of assessing and evaluating the viability of conducting remanufacturing, and how have they met the requirements of the decision stage. Section 2 provides a framework to establish the requirements of this decision process, identifying key decision factors, the different stages at which the decision can be conducted and the challenges of decision making for remanufacturing. This next section provides the detailed methodology into how the review of the tools and methods for remanufacturing evaluation is conducted.

A content analysis has been conducted for this study. In contrast to traditional or narrative literature reviews, a content analysis uses a clear research procedure and explicitly states methods for selecting and evaluating publications (Boehm and Thomas, 2013). This approach enables greater transparency to the entire review process, thus giving the study greater scientific validity as the process becomes repeatable. This type of review is frequently used within the medical and pharmaceutical domain and is becoming more popular within the business studies area. Three key stages are outlined within the methodology of the study (Boehm and Thomas, 2013), these are:

1. Scope of the study

2. Search Strategy

3. Evaluation of material method

The first step is to define the scope of the study by delimiting literature, defining clear boundaries of what is and is not to be included. The delimitations of this study excluded publications as follows;

- older than 10 years (before 2003)

- tools designed to assist with production planning of remanufacturing, reverse logistics and disassembly sequencing, as these focused upon optimising a process rather than addressing the key subject of this paper that is to determine whether to conduct remanufacture.

- the analysis was limited to English written peer reviewed journal papers or published conference papers.

The first delimitation of the study is to exclude publications before 2003. This allows for the previous 10 years to analysed, to focus on the most up to date tools and methods. The second delimitation is based upon the decision that the tool and method supports. The intention of this paper is to focus upon the decision of whether to remanufacture. Tools which do not meet this key requirement are therefore excluded. This exclusion includes tools aimed at optimising production planning and inventory management decisions, reverse logistics planning and disassembly sequencing. Although these areas overlap and can influence the decision making process, ultimately they seek to optimise a particular aspect of remanufacturing, rather than decide whether or not to remanufacture. Finally the study is limited to English written peer reviewed journal papers or published conference papers.

The search strategy used for collecting material for this review is now discussed. The approach is described in Figure 4. Firstly a structured keyword search of three well established bibliographic databases was conducted to obtain relevant material. The databases chosen for the search were Compendex, Scopus and Web of knowledge. These databases were chosen due to their wide coverage of the engineering and manufacturing domain, along with the inclusion of key academic 
journals within the area, such as the Journal of Cleaner Production and International Journal of Production Research. All keywords searches contained the term 'Remanufactur*' using the wildcard '*' to ensure results also included the terms such as remanufacture, remanufacturing and remanufacturability. This was coupled with additional keywords associated with decision making such as evaluation and assessment. Full search terms and results are shown in Table 6. A combined total of 1352 papers were found from this initial search.

Table 6 Keyword search results for each database (note each keyword was coupled with the term 'remanufactur*' using the \& operator)

\begin{tabular}{|l|l|l|l|}
\hline Keyword Search & $\begin{array}{l}\text { Web of } \\
\text { Knowledge }\end{array}$ & Compendex & Scopus \\
\hline Feasibility & 47 & 77 & 55 \\
\hline Assessment & 61 & 98 & 80 \\
\hline Evaluation & 75 & 153 & 91 \\
\hline Decision making & 161 & 142 & 151 \\
\hline Decision support & 26 & 34 & 33 \\
\hline Decision Tool & 21 & 22 & 25 \\
\hline
\end{tabular}

Duplicates were then removed to leave a total of 558 unique publications. A two stage manual search was then conducted of the individual publications to remove those outside of the delimited criteria. The first involved viewing publication title to remove those that were clearly outside of the delimited scope. The abstracts of the publications remaining were then viewed to further remove those outside the scope of this study. After the manual search process 44 publications were identified as being relevant to this study.

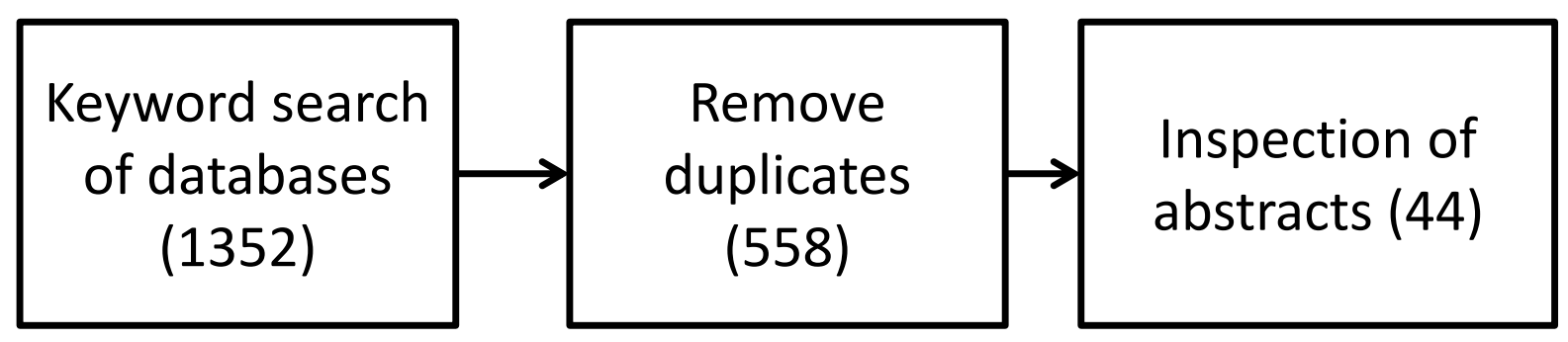

Figure 4 The material collection methodology 
Finally the approach to evaluation of the material is described. Each article found is categorised based upon specific decision application of the tool, as shown in

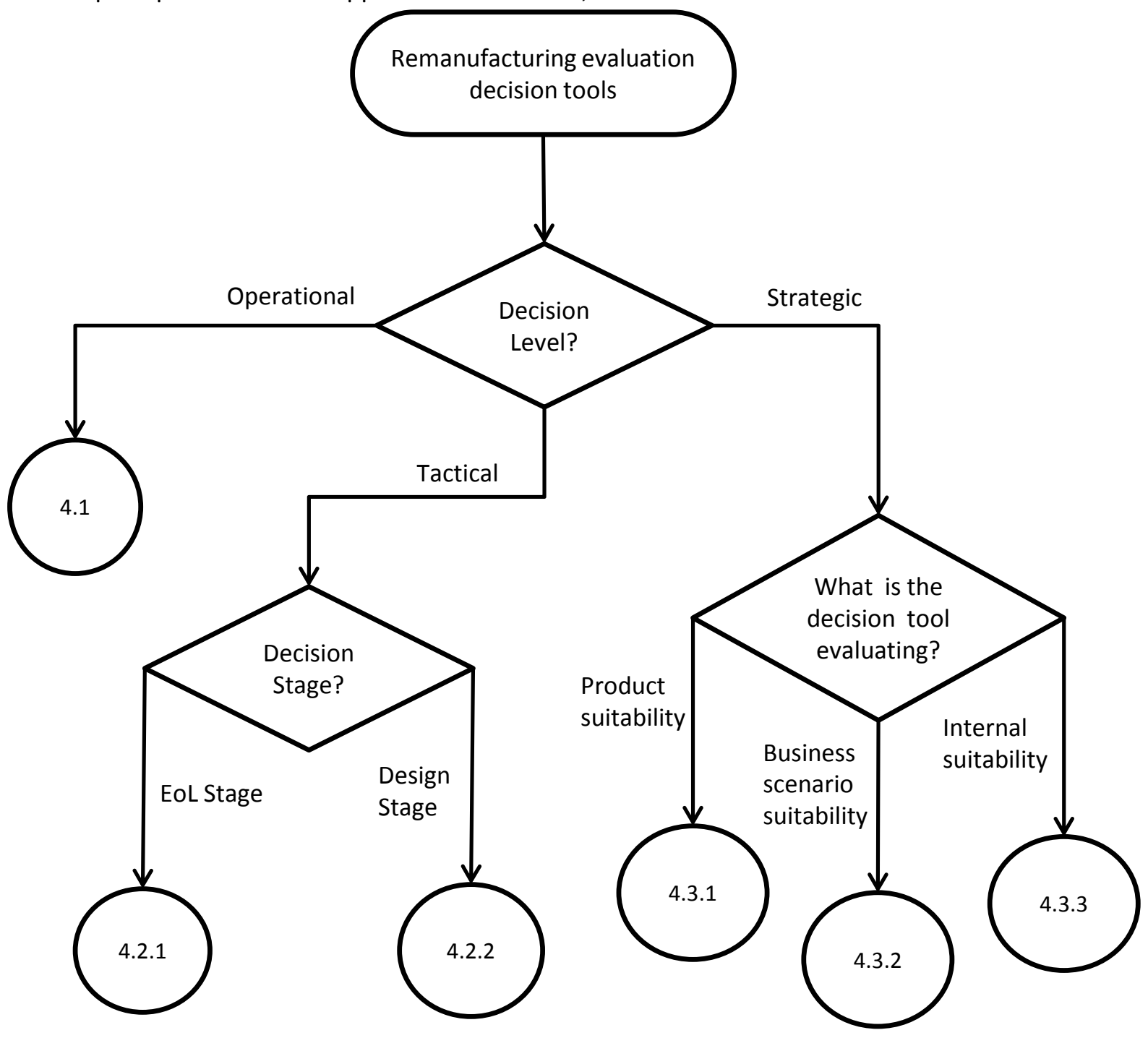

Figure 5. These categories were generated using the decision levels identified in the previous section; Strategic, tactical and operational. Further categorisation was then performed inductively, based upon the specific decision application found within the tools. Using the background summary of the decision making process from section 2 , each tool is then evaluated upon how it meets the demand of the decision making process. Table 7 shows the specific analytic categories which the tools are evaluated against. 


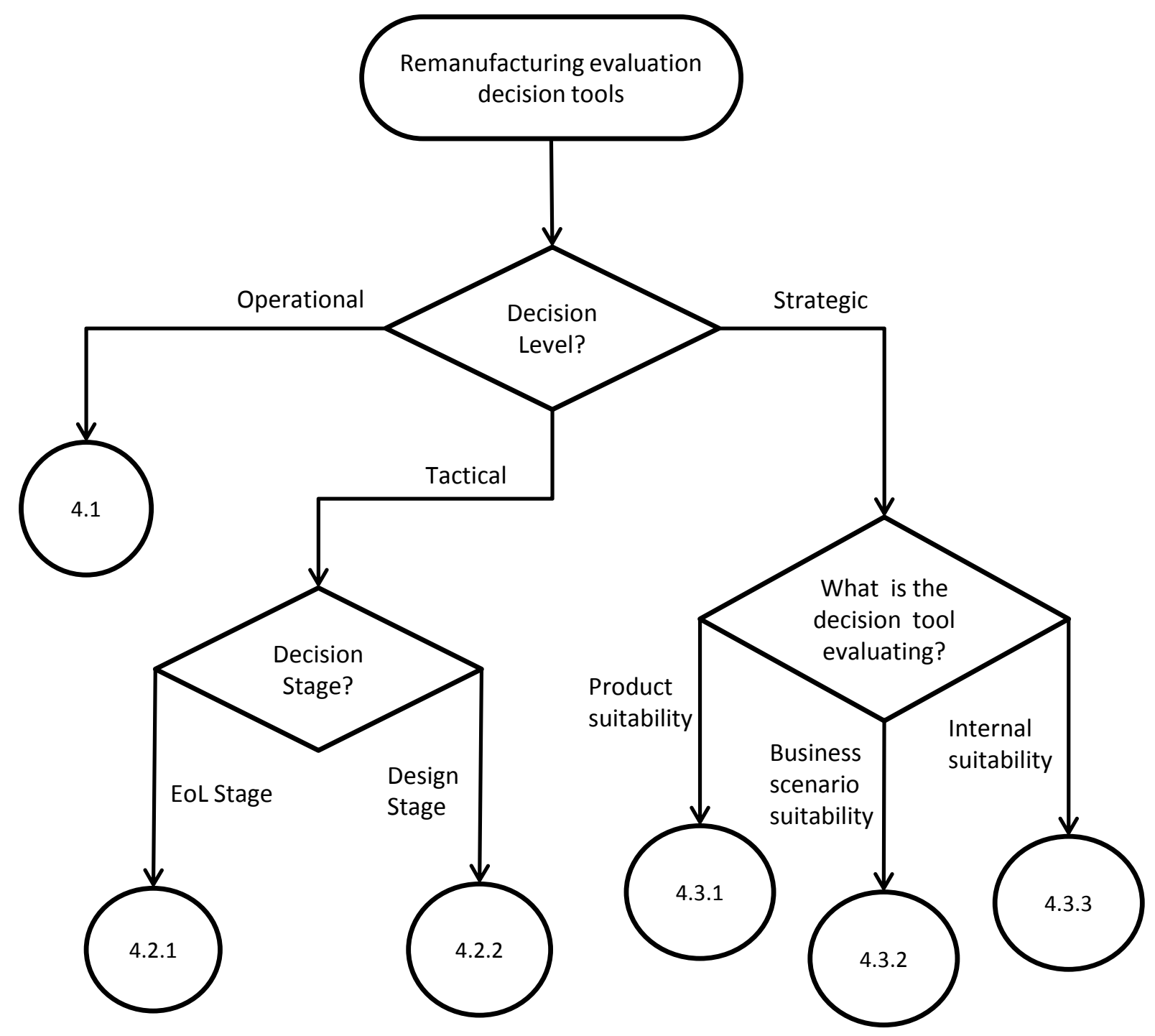

Figure 5 Process for categorising tools based upon functionality

Using the key research objective outlined in section 1, the key analytic assessment categories identified were; the decision factors used to assess feasibility, how well uncertainty is factored into the decision making process. After analysing the tools and methods further categories were included; the type of data input, the purpose of the tool. A full description of each analytic category can be found in Table 7.

Table 7 Categories used to analyse tools

\begin{tabular}{|c|c|c|}
\hline \multicolumn{2}{|l|}{ Analytic Category } & Description \\
\hline \multicolumn{2}{|c|}{ Tool Description } & Brief description of the tool \\
\hline \multirow[t]{3}{*}{ 2. Decision } & 2.1 Economic & \multirow{3}{*}{$\begin{array}{l}\text { Assess the coverage of the key decision factors } \\
\text { found in section } 2 \text { (see Figure } 3 \text { ) } \\
\mathrm{O}=\text { Decision factors not considered } \\
\mathrm{X}=\text { Partial consideration of decision factors } \\
\mathrm{XX}=\text { Decision factors well covered }\end{array}$} \\
\hline & 2.2 Environmental & \\
\hline & 2.3 Social & \\
\hline \multicolumn{2}{|c|}{ 3. Data input type } & Either quantitative or qualitative \\
\hline \multicolumn{2}{|c|}{ 4. Considers Uncertainty? } & Factors for uncertainty within data input \\
\hline
\end{tabular}




\section{Results}

\subsection{Operational Tools}

Operational tools are summarised in Table 8. These are used to evaluate a specific product instance for remanufacture, such as that occurs within a remanufacturing facility during the inspection phase. The important aspect which is considered here is the condition of the product which is being evaluated for remanufacture. Zhou et al (2012) focuses upon evaluating the quality of the product for remanufacture, through the assessment of several measurements and inspections. A reusability score is then calculated using a fuzzy Analytic Hierarchical Process (AHP). In some of the tools, the condition is assumed to be known prior to arrival at the remanufacturing facility, through technologies such as sensor embedded products (Jun et al., 2007; Jun et al., 2012). Using this information Jun et al (2007) develop a cost model to assess the best EoL strategy for components within a Turbocharger. Jun et al (2012) expands upon this approach to consider multiple products, such as found in a batch remanufacturing environment. Kumar et al (2007) uses product condition as a decision factor within a satisfaction metric in which it is expressed as a function of a product's time in use.

Table 8 Operational tools

\begin{tabular}{|c|c|c|c|c|c|c|}
\hline \multirow{3}{*}{$\begin{array}{l}\text { Decision Stage } \\
\text { Paper reference }\end{array}$} & \multicolumn{6}{|l|}{ Operational } \\
\hline & \multirow{2}{*}{ Tool Description } & \multicolumn{3}{|c|}{ Decision Factors } & \multirow{2}{*}{$\begin{array}{l}\text { Data Input } \\
\text { Type }\end{array}$} & \multirow{2}{*}{$\begin{array}{l}\text { Considers } \\
\text { Uncertainty? }\end{array}$} \\
\hline & & Economic & $\begin{array}{l}\text { Environ- } \\
\text { mental }\end{array}$ & Social & & \\
\hline Zhou et al (2012) & $\begin{array}{l}\text { Quality evaluation model } \\
\text { to assess reusability and } \\
\text { component management } \\
\text { system. }\end{array}$ & $\mathrm{X}$ & $\mathrm{O}$ & $\mathrm{O}$ & Quantitative & $\mathrm{X}$ \\
\hline Jun et al (2012) & $\begin{array}{l}\text { Product recovery } \\
\text { optimisation algorithm to } \\
\text { minimise cost under } \\
\text { quality constraint }\end{array}$ & $X X$ & $\mathrm{O}$ & $\mathrm{O}$ & Quantitative & $\mathrm{X}$ \\
\hline Jun et al (2007) & $\begin{array}{l}\text { Product recovery } \\
\text { optimisation algorithm to } \\
\text { minimise cost under } \\
\text { quality constraint }\end{array}$ & $X X$ & $\mathrm{O}$ & $\mathrm{O}$ & Quantitative & $\mathrm{O}$ \\
\hline Kumar et al (2007) & $\begin{array}{l}\text { An EoL decision method } \\
\text { based upon a model to } \\
\text { characterise the value flow } \\
\text { during a product lifecycle }\end{array}$ & $X X$ & $\mathrm{O}$ & $\mathrm{X}$ & Quantitative & $\mathrm{X}$ \\
\hline
\end{tabular}

\subsection{Tactical Tools}

The aim of these tools is to evaluate a particular product design to determine appropriate end of life strategies for individual components. This evaluation is of a specific product design in which subassemblies and components are represented using a Bill of Materials (BoM). The difference between these tools and the operational tools above is that MoL effects are neglected, such as the condition of the returned product. The use of these tools include evaluating best practice for remanufacturing facilities at the EoL and evaluating product designs at the product design stage.

\subsubsection{EoL Stage}

Economic factors have been widely used in determining the EoL actions for the products and components. Evaluating the value and cost of both remanufacture and alternative EoL options is the most common method of determining economic factors. The value of EoL options are usually 
evaluated at a high level and expressed using a quantitative monetary market value. These values are usually derived from expert knowledge and aim to estimate current market value. The cost of each EoL option is usually assessed in greater depth than the value. Costs are broken down into key areas such as the acquisition, logistics, disassembly and rework. Xanthopoulos and lakovou (2009) go into greater depth by accounting for additional costs of production planning issues such as emergency procurement, backorders and emergency set up costs.

Alternatively metrics can be used as an indicator of remanufacturing costs, rather than a direct economic analysis. Factors considered when creating these metrics include ease of conducting remanufacturing activities (Du et al., 2012), historical failure data (Anityasari and Kaebernick, 2008) and variability within a product design (Pandey and Thurston, 2010). These indirectly enable the evaluation of economic factors described in section 2.2 .

Environmental factors have been considered by many of the tools during decision making. Quantitative metrics have been used within several of the tools to calculate environmental impacts. The Eco-indicator 99 metric developed by PRé Consultants (2000), which considers damage to human health, ecosystems and resources, has been used by Shrivastava et al (2005) and Zhang et al (2004), other methods express environmental costs as pure economic values (Ghazalli and Murata, 2011). Social factors have been partially assessed by Shrivastava et al (2005) and Zhang et al (2004) within the eco-indicator 99 metric, which includes human health scores (PRé Consultants, 2000).

Five of the tools enable uncertainty within decision factors to be conveyed. Quantitative techniques such as stochastic simulation and Monte Carlo analysis have been used to enable the expression of parameters such as return quantity (Behdad et al., 2012;Xanthopoulos and lakovou, 2009), product life span (Anityasari and Kaebernick, 2008) and product demand (Xanthopoulos and lakovou, 2009). Qualitative techniques have been employed when it has been difficult to express a factor in a quantitative manner. Du et al (2012) use a scoring system (1-10) to allow expert users to qualitatively express the pollution reduction through remanufacturing.

Table 9 Tactical EoL stage tools

\begin{tabular}{|c|c|c|c|c|c|c|}
\hline Decision Stage & Tactical: EoL Stage & & & & & \\
\hline Paper & Tool Description & Decision F & ctors & & Data Input & Considers \\
\hline & & Economic & $\begin{array}{l}\text { Environ } \\
\text {-mental }\end{array}$ & Social & & \\
\hline $\begin{array}{l}\text { Behdad et al } \\
(2012)\end{array}$ & $\begin{array}{l}\text { A stochastic programming } \\
\text { model based upon uncertain } \\
\text { return quantity to determine } \\
\text { level of disassembly and } \\
\text { component EoL strategy }\end{array}$ & $\mathrm{XX}$ & $\mathrm{O}$ & $\mathrm{O}$ & Quantitative & $\mathrm{XX}$ \\
\hline Du et al (2012) & $\begin{array}{l}\text { An integrated method for } \\
\text { evaluating remanufacturability } \\
\text { of used machine tools }\end{array}$ & $\mathrm{XX}$ & $X X$ & $\mathrm{O}$ & Mixed & $\mathrm{O}$ \\
\hline $\begin{array}{l}\text { Ghazalli and } \\
\text { Murata (2011) }\end{array}$ & $\begin{array}{l}\text { Component EoL strategy } \\
\text { selection algorithm }\end{array}$ & $X X$ & $X X$ & $\mathrm{O}$ & Quantitative & $\mathrm{X}$ \\
\hline Lee et al (2010) & $\begin{array}{l}\text { Component EoL strategy } \\
\text { decision algorithm and } \\
\text { disassembly sequence } \\
\text { optimiser }\end{array}$ & $\mathrm{XX}$ & $\mathrm{X}$ & $\mathrm{O}$ & Quantitative & $\mathrm{O}$ \\
\hline $\begin{array}{l}\text { Pandey and } \\
\text { Thurston (2010) }\end{array}$ & $\begin{array}{l}\text { A method for making } \\
\text { component level EoL } \\
\text { decisions based upon } \\
\text { component criticality and } \\
\text { remanufacturing system } \\
\text { variability. }\end{array}$ & $\mathrm{X}$ & $\mathrm{X}$ & $\mathrm{O}$ & Qualitative & $\mathrm{X}$ \\
\hline
\end{tabular}




\begin{tabular}{|l|l|l|l|l|l|l|}
\hline $\begin{array}{l}\text { Xanthopoulos } \\
\text { and lakovou } \\
(2009)\end{array}$ & $\begin{array}{l}\text { An algorithm to select product } \\
\text { EoL strategy and optimise } \\
\text { recovery operations }\end{array}$ & $\mathrm{XX}$ & $\mathrm{X}$ & $\mathrm{O}$ & Mixed \\
\hline $\begin{array}{l}\text { Anityasari and } \\
\text { Kaebernick } \\
(2008)\end{array}$ & $\begin{array}{l}\text { A method for evaluating } \\
\text { reliability of products for reuse } \\
\text { and remanufacture }\end{array}$ & $\mathrm{X}$ & $\mathrm{X}$ & $\mathrm{O}$ & $\mathrm{X}$ \\
\hline $\begin{array}{l}\text { Gonzalez and } \\
\text { Adenso-Diaz } \\
(2005)\end{array}$ & $\begin{array}{l}\text { Component EoL strategy } \\
\text { decision algorithm and } \\
\text { disassembly sequence } \\
\text { optimiser }\end{array}$ & $\mathrm{XX}$ & $\mathrm{X}$ & $\mathrm{O}$ & Quantitative & O \\
\hline $\begin{array}{l}\text { Shrivastava et } \\
\text { al (2005) }\end{array}$ & $\begin{array}{l}\text { A web based system for } \\
\text { evaluating product EoL }\end{array}$ & $\mathrm{XX}$ & $\mathrm{XX}$ & $\mathrm{X}$ & $\mathrm{XX}$ \\
\hline $\begin{array}{l}\text { Zhang et al } \\
\text { (2004) }\end{array}$ & $\begin{array}{l}\text { A web based system for } \\
\text { evaluating product EoL }\end{array}$ & $\mathrm{XX}$ & $\mathrm{XX}$ & $\mathrm{X}$ & Quantitative & $\mathrm{O}$ \\
\hline
\end{tabular}

\subsubsection{Product Design}

The second set of tools aimed at a tactical level have been developed to assist with the product design stage. Designers can use these tools to evaluate the suitability of a product design for remanufacture and make adjustments if required.

Economic factors again play the largest role within the decision making process. However, as the decision is being assessed at the beginning of the product life cycle rather than at the end, greater uncertainty is present, as values need to be forecast.

The use of metrics to evaluate decision factors has been widely adopted within these tools, which avoids the need for a direct cost analysis. Xing et al (2007), and Xing and Luong (2009) develop metrics in order to evaluate a products' upgradeability through remanufacture based upon technological, functional, physical and structural factors. A mixture of quantitative and qualitative data inputs are used to construct the metrics. Quantitative values are used to evaluate current and future product performance metrics, whist fuzzy logic is used to express values which are difficult to quantitatively evaluate, such as component link strength.

Krill and Thurston (2005) use a direct quantitative approach in calculating economic cost and environmental impact to assess the effects associated with sacrificial cylinder liners to enable remanufacturing of engine blocks. An activity based model is employed to determine original production and remanufacturing costs, whilst environmental impacts are calculated using a commercial Life Cycle Assessment (LCA) package. LCA has been used solely to determine the environmental impacts for remanufacturing products such as engines (Adler et al., 2007; Smith and Keoleian, 2004; Yang and Chen, 2005), and telecommunications equipment (Goldey et al., 2010). Emphasis here is placed upon comparing remanufacturing to manufacturing using quantitative environmental factors such as energy consumption, $\mathrm{CO} 2$ emissions and material waste.

Table 10 Tactical product design stage tools

\begin{tabular}{|c|c|c|c|c|c|c|}
\hline Decision Stage & Tactical: Design Stage & & & & & \\
\hline Paper & Tool Description & Decision F & ctors & & Data Input & Considers \\
\hline reте & & Economic & $\begin{array}{l}\text { Environ- } \\
\text { mental }\end{array}$ & Social & $1 y$ & nty? \\
\hline $\begin{array}{l}\text { Iberahim et al } \\
(2011)\end{array}$ & $\begin{array}{l}\text { A method for evaluating } \\
\text { component remanufacturability }\end{array}$ & $\mathrm{X}$ & $\mathrm{O}$ & $\mathrm{O}$ & Quantitative & $\mathrm{O}$ \\
\hline Li and Li (2011) & $\begin{array}{l}\text { Technical and economic } \\
\text { analysis of remanufacturing } \\
\text { through a profit objective } \\
\text { function }\end{array}$ & $\mathrm{X}$ & $\mathrm{X}$ & $\mathrm{X}$ & Quantitative & $\mathrm{O}$ \\
\hline
\end{tabular}




\begin{tabular}{|c|c|c|c|c|c|c|}
\hline $\begin{array}{l}\text { Schau et al } \\
\text { (2011) }\end{array}$ & $\begin{array}{l}\text { Life cycle cost model for } \\
\text { evaluating product design } \\
\text { alternatives and locations for } \\
\text { conducting remanufacture }\end{array}$ & $X X$ & $\mathrm{O}$ & $\mathrm{O}$ & Quantitative & $\mathrm{X}$ \\
\hline $\begin{array}{l}\text { Goldey et al } \\
(2010)\end{array}$ & $\begin{array}{l}\text { Life cycle assessment using } \\
\text { the commercially available } \\
\text { GaBi } 4.0 \text { software. }\end{array}$ & $\mathrm{O}$ & $X X$ & $\mathrm{O}$ & Quantitative & $\mathrm{O}$ \\
\hline $\begin{array}{l}\text { Wang and } \\
\text { Tseng (2010) }\end{array}$ & $\begin{array}{l}\text { Methodology to assist product } \\
\text { design and component EoL } \\
\text { selection through the use of } \\
\text { life cycle commonality metrics } \\
\text { (LCCM) and economic } \\
\text { analysis }\end{array}$ & $X X$ & $\mathrm{O}$ & $\mathrm{O}$ & Quantitative & $\mathrm{O}$ \\
\hline $\begin{array}{l}\text { Xing and Luong } \\
(2009)\end{array}$ & $\begin{array}{l}\text { Mathematical model to assess } \\
\text { product for service life } \\
\text { extension through } \\
\text { remanufacture }\end{array}$ & $X X$ & $\mathrm{O}$ & $\mathrm{O}$ & Mixed & $x$ \\
\hline $\begin{array}{l}\text { Adler et al } \\
(2007)\end{array}$ & $\begin{array}{l}\text { Life cycle assessment of } \\
\text { original manufacturing and } \\
\text { remanufacturing in engine } \\
\text { components using SimaPro } \\
7.0\end{array}$ & $\mathrm{O}$ & $X X$ & $\mathrm{O}$ & Quantitative & $\mathrm{O}$ \\
\hline $\begin{array}{l}\text { Xing et al } \\
(2007)\end{array}$ & $\begin{array}{l}\text { Mathematical model to assess } \\
\text { product upgradeability for } \\
\text { remanufacture }\end{array}$ & $X X$ & $\mathrm{O}$ & $\mathrm{O}$ & Mixed & $\mathrm{X}$ \\
\hline $\begin{array}{l}\text { Krill and } \\
\text { Thurston (2005) }\end{array}$ & $\begin{array}{l}\text { Spreadsheet based tool to } \\
\text { estimate cost and } \\
\text { environmental impact of using } \\
\text { sacrificial cylinder liners for } \\
\text { remanufacturer }\end{array}$ & $X X$ & $X X$ & $\mathrm{O}$ & Quantitative & $\mathrm{O}$ \\
\hline $\begin{array}{l}\text { Yang and Chen } \\
(2005)\end{array}$ & $\begin{array}{l}\text { Life Cycle Assessment of } \\
\text { engine remanufacturing }\end{array}$ & $\mathrm{O}$ & $X X$ & $\mathrm{O}$ & Quantitative & $\mathrm{O}$ \\
\hline $\begin{array}{l}\text { Smith and } \\
\text { Keoleian (2004) }\end{array}$ & $\begin{array}{l}\text { Life Cycle Assessment of } \\
\text { engine remanufacturing }\end{array}$ & $\mathrm{O}$ & $X X$ & $\mathrm{O}$ & Quantitative & $\mathrm{O}$ \\
\hline $\begin{array}{l}\text { Daimon et al } \\
(2003)\end{array}$ & $\begin{array}{l}\text { Decision support method for } \\
\text { life cycle strategy by } \\
\text { estimating value and physical } \\
\text { lifetimes }\end{array}$ & $\mathrm{X}$ & $\mathrm{O}$ & $\mathrm{O}$ & Quantitative & $\mathrm{x}$ \\
\hline
\end{tabular}

\subsection{Strategic Tools}

Strategic tools have been designed to assist decision makers in assessing remanufacturing feasibility at a strategic level. Many of the tools found have been designed to address specific aspects of strategic decision making, therefore these tools have been separated into three key categories. The first evaluates the suitability of a product for remanufacture. This is similar to the tactical tools however it is assessed at a higher level which requires less certainty in the product detail, such as the BoM. The second main category assesses remanufacturing as an option for use within a particular business strategy. The third category assesses the suitability of conducting remanufacturing within a particular business, with emphasis being placed upon the internal requirements of the business to perform remanufacturing activities.

\subsubsection{Product Suitability}

Product suitability tools are summarised within Table 11. These tools enable the evaluation of a product for remanufacture or alternate EoL option at a strategic level, thus requiring less crisp and tangible information than at either operational or tactical stages. Decisions tend to be made at the product level rather than individual component or subassembly due to the conceptual level nature of the decision.

Economic, including technological factors are again key to the decision making process and feature in many of the tools, as shown in Table 11. Information such as 'number of parts', 'technology cycle 
(years)' and 'wear out life (years)' are required by the tools (Gehin et al., 2008;Ghazalli and Murata, 2011; Thomas Chen and Jun-Nan Wu, 2003). Environmental factors are also used to influence the decision, although these tend to be qualitative in nature. Questions such as 'If disposed, will the component be harmful to the environment' are proposed, with linguistic values such as 'high' and 'low' used to respond to the question (Pochampally and Gupta, 2012). Social factors play only a small part in the decision making process, with only minor references to these aspects found.

Due to the conceptual nature of these tools, uncertainty has been largely incorporated into the decision inputs. Bayesian updating and fuzzy logic have been used to enable qualitative linguistic inputs into a quantitative model (Pochampally et al., 2004;Pochampally and Gupta, 2012). Case based reasoning has been used by Ghazalli and Murata (2011) to enable comparisons to be drawn with past cases where appropriate EoL strategies have been calculated.

Table 11 General EoL classification tools for strategic product suitability

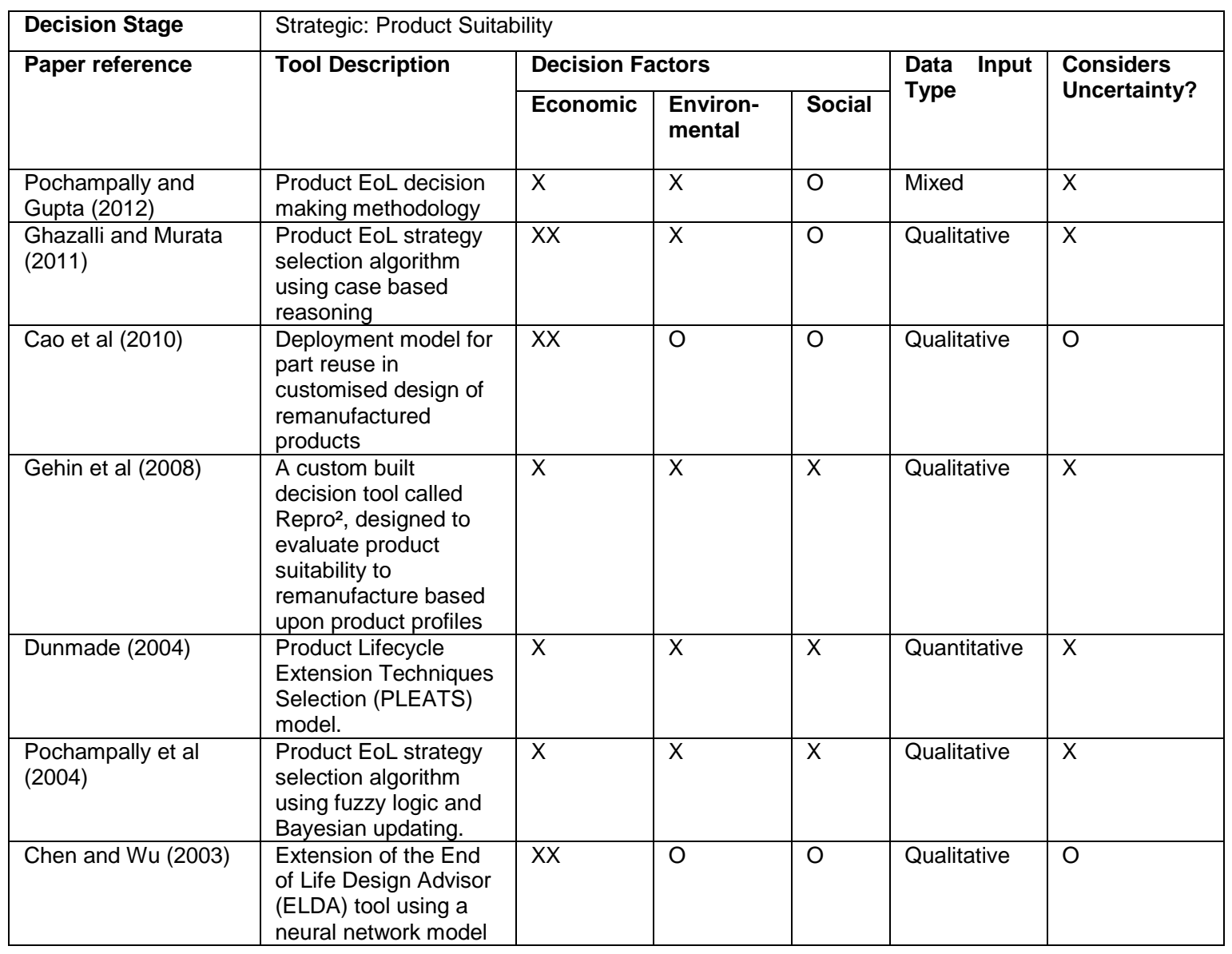

\subsubsection{Business scenario suitability}

A number of tools have been developed to assist decision makers assessing the impact of employing remanufacturing as part of a business strategy. Business scenarios in which remanufacturing is addressed include sales to secondary markets (Quariguasi-Frota-Neto and Bloemhof, 2012), spare parts for aftermarket sales (Inderfurth and Mukherjee, 2008;McKenna et al., 2013), and PSS (Intlekofer et al., 2010;Spengler and Stolting, 2008). 
Spengler and Stolting (2008) evaluate the effect of strategic business decisions such as incorporating design for remanufacturing, the business organisational structure, the returns incentive system and the process capacity upon life cycle product costs. Inderfurth and Mukherjee (2008) assess the potential strategies to fulfil demand for aftermarket spare parts, namely through namely a long single batch run, frequent but small production batches or remanufacturing.

Boustani et al (2010) evaluates both the economic and environmental consequences of remanufacturing appliances over a product life time. Here product technology improvements are considered overtime, thus energy use within the use phase becomes increasingly important. McKenna et al (2013) develops a model to evaluate the energy savings made through direct reuse and remanufacturing with the German automotive spare parts sector, whilst Intlekofer et al (2010) evaluate the energy implications of a product leasing strategy combined with remanufacturing.

Quariguasi-Frota-Neto and Bloemhof (2012) evaluate the eco-efficiency of remanufacturing of mobile phones and personal computers. Here eco-efficiency is defined as the ratio of welfare created to environmental impact.

Table 12 Business scenario suitability decision tools

\begin{tabular}{|c|c|c|c|c|c|c|}
\hline \multirow{3}{*}{$\begin{array}{l}\text { Decision Stage } \\
\text { Paper reference }\end{array}$} & \multicolumn{6}{|c|}{ Strategic: Business Scenario Suitability } \\
\hline & \multirow[t]{2}{*}{ Tool Description } & \multicolumn{3}{|c|}{ Decision Factors } & \multirow{2}{*}{$\begin{array}{l}\text { Data Input } \\
\text { Type }\end{array}$} & \multirow{2}{*}{$\begin{array}{l}\text { Considers } \\
\text { Uncertainty? }\end{array}$} \\
\hline & & Economic & $\begin{array}{l}\text { Environ- } \\
\text { mental }\end{array}$ & Social & & \\
\hline $\begin{array}{l}\text { McKenna et al } \\
(2013)\end{array}$ & $\begin{array}{l}\text { A method for evaluating } \\
\text { the energy savings } \\
\text { through direct } \\
\text { secondary reuse and } \\
\text { remanufacture within } \\
\text { the German automotive } \\
\text { sector }\end{array}$ & $\mathrm{O}$ & $\mathrm{XX}$ & $\mathrm{O}$ & Quantitative & $\mathrm{O}$ \\
\hline $\begin{array}{l}\text { Quariguasi-Frota- } \\
\text { Neto and Bloemhof } \\
\text { (2012) }\end{array}$ & $\begin{array}{l}\text { Mathematical model to } \\
\text { evaluate eco efficiency } \\
\text { remanufacturing versus } \\
\text { virgin manufacturing }\end{array}$ & $\mathrm{XX}$ & $X X$ & $\mathrm{XX}$ & Quantitative & $\mathrm{O}$ \\
\hline Intlekofer et al (2010) & $\begin{array}{l}\text { Mathematical model to } \\
\text { compare life cycle } \\
\text { energy consumption of } \\
\text { different business } \\
\text { scenarios }\end{array}$ & 0 & $X X$ & $\mathrm{O}$ & Quantitative & $\mathrm{O}$ \\
\hline Boustani et al (2010) & $\begin{array}{l}\text { Life cycle costing (LCC) } \\
\text { and assessment (LCA ) } \\
\text { methods used to } \\
\text { evaluate the energy } \\
\text { savings and economic } \\
\text { impact of appliance } \\
\text { remanufacture }\end{array}$ & $\mathrm{XX}$ & $\mathrm{XX}$ & $\mathrm{O}$ & Quantitative & $\mathrm{O}$ \\
\hline $\begin{array}{l}\text { Inderfurth and } \\
\text { Mukherjee (2008) }\end{array}$ & $\begin{array}{l}\text { Decision support for } \\
\text { spare parts acquisition }\end{array}$ & $X X$ & $\mathrm{O}$ & $\mathrm{O}$ & Quantitative & $\mathrm{XX}$ \\
\hline $\begin{array}{l}\text { Spengler and } \\
\text { Stolting (2008) }\end{array}$ & $\begin{array}{l}\text { Life cycle costing model } \\
\text { to evaluate the effect of } \\
\text { certain business } \\
\text { decisions on a product } \\
\text { life cycle cost }\end{array}$ & $\mathrm{XX}$ & $\mathrm{O}$ & $\mathrm{O}$ & Quantitative & $\mathrm{X}$ \\
\hline
\end{tabular}

\subsubsection{Internal suitability}

The last set of strategic decision tools evaluate the ability of a business in conducting remanufacturing. These tools are designed to allow businesses to internally assess themselves to 
determine their suitability for undertaking remanufacturing. Subramoniam et al (2013) provides a decision making framework in which key decision factors are highlighted for assessment. Wang and Li (2011) use neural networks to evaluate the risk within a remanufacturing business, based upon key remanufacturing activities such as acquisition, disassembly and reprocessing.

Table 13 Internal suitability decision tools

\begin{tabular}{|c|c|c|c|c|c|c|}
\hline \multirow{3}{*}{$\begin{array}{l}\text { Decision Stage } \\
\text { Paper reference }\end{array}$} & \multicolumn{6}{|l|}{ Strategic: Internal Suitability } \\
\hline & \multirow[t]{2}{*}{ Tool Description } & \multicolumn{3}{|c|}{ Decision Factors } & \multirow{2}{*}{$\begin{array}{l}\text { Data } \\
\text { Input } \\
\text { Type }\end{array}$} & \multirow{2}{*}{$\begin{array}{l}\text { Considers } \\
\text { Uncertainty? }\end{array}$} \\
\hline & & Economic & $\begin{array}{l}\text { Environ- } \\
\text { mental }\end{array}$ & Social & & \\
\hline $\begin{array}{l}\text { Subramoniam et al } \\
\text { (2013) }\end{array}$ & $\begin{array}{l}\text { Remanufacturing decision } \\
\text { making framework for } \\
\text { assessing business suitability } \\
\text { for employing } \\
\text { remanufacturing operations }\end{array}$ & $\mathrm{XX}$ & $\mathrm{X}$ & $\mathrm{X}$ & Qualitative & $\mathrm{X}$ \\
\hline Wang and $\mathrm{Li}$ (2011) & $\begin{array}{l}\text { Risk assessment for a } \\
\text { remanufacturing system } \\
\text { based upon neural network }\end{array}$ & $\mathrm{XX}$ & $\mathrm{O}$ & $\mathrm{O}$ & Qualitative & $X X$ \\
\hline
\end{tabular}

\section{Discussion}

\subsection{Decision factors}

Economic decision factors are the most widely used to assess the remanufacturability within the decision tools with 35/41 incorporating these issues. Both the value and costs of remanufacturing have been widely used to evaluate the economic potential. The resale price of remanufactured products is the most widely used factor in determining the value of remanufacturing, which is often compared to process costs as a direct economic analysis. The process costs of remanufacturing have been the most widely used factor of all the decision tools. The method for expressing this factor varies considerably, from an explicit quantitative value such as fixed cost for the whole process or a detailed parametric cost model (Krill and Thurston, 2005), to implicit qualitative answers to questions such as 'How difficult is product $X$ to disassemble'. The linkage of product design to remanufacturing cost is commonly used within the tools as a means of decision making. MoL impacts to the product condition are a key factor within operational level tools. The effect of process related issues, such as capacity limits, are the least considered factor found within the tools, with only Behdad et al. (2012), and Xanthopoulos and lakovou (2009) seriously evaluating these features. It is perhaps understandable to exclude this factor for conceptual decision stages, such as strategic and product design, however it can play an import role, particularly at the operational stages.

Environmental factors have been widely considered, with 25 tools including these issues within the decision process. The measurement of the environmental impact has been the most proficient means of considering this factor, with the eco-indicator 99 often being used. Additional measurement techniques focus upon specific environmental impacts, such as the Cumulative Energy Demand (CED) employed by Quariguasi-Frota-Neto and Bloemhof (2012) which focuses upon the energy used within a process. Qualitative methods have also been used to indicate environmental factors when quantitative LCA techniques cannot be employed. These may include simple questions such as 'what is the environmental impact of disposal' in which expert user knowledge is required to answer the question. The boundaries on which environmental impacts are calculated vary between 
the tools. Many purely assess the impact at the EoL, whilst others may include full life cycle effects which may include use phase differences from upgraded or new technologies.

Finally social impacts of remanufacturing took lowest priority within the tools, with only 9 considering these impacts within the decision process. The eco-indicator 99 metric, used by some of the tools, partially covers social factors as it contains a smaller metric called the human health index, which considers damages to human health from environmental causes (PRé Consultants, 2000). Social factors are probably most valuable to assess early within the decision process such as the strategic evaluation stage, so future scope is available to include these factors within the business strategy tools.

\subsection{Decision Stage}

Emphasis within decision tool development has predominately been focused upon tactical and strategic levels. Of the 41 tools assessed within this paper, only 4 have been designed for use at the operational level.

Understanding and utilising effective MoL information to make remanufacturing and other EoL decisions is an important part of the operational tools. With the ability to access MoL information through technologies such as embedded sensors, remanufacturers can reduce uncertainties surrounding returned product condition. However, to make full use of this information, remanufacturers must understand how MoL information should be used to inform the remanufacturing decision. None of the tools enable decision makers to relate raw MoL and inspection data, to the direct effects upon the remanufacturing process. Further, none of the operational tools found considered process conditions, such as inventory levels or process queues. Currently each of these areas are addressed individually, such as converting raw inspection data into an overall condition metric (Zhou et al., 2012) and using overall condition and other metrics as a decision making factors (Jun et al., 2007; Jun et al., 2012). Integration of these features is an area in which future decision making tools could incorporate into their functionality.

Tactical decision tools were found to have received relatively large amount of attention from academia. The main focus within these tools is the evaluation of a product design at a component level for remanufacture. This is particularly useful for remanufacturing businesses with a good understanding of the products which will be received for remanufacture, such as OEMs.

Although several tools have been found to help assess product remanufacturability at a high level, more work could be done to allow strategic decision makers to assess how remanufacturing affects particular business scenarios or strategy. Supply of aftermarket spare parts is a major business application for remanufacturing, however few tools were found to specifically assess remanufacturing as an option for satisfying this business scenario.

\subsection{Uncertainty}

Many of the decision tools found within this study lacked the capability of expressing the uncertainty regarding an input variable. Often a crisp value is required as an input, such as remanufacturing cost, where in reality this figure will carry a degree of uncertainty due to the factors described in section 2.4. The quantification of this uncertainty could allow decision makers to evaluate the associated risk with a decision. 
Those that have expressed uncertainty within the tools do so in either a quantitative or qualitative manner. The quantitative approach often involves the use of stochastic programing, used by Behdad et al (2012) and Anityasari et al (2005) to model the uncertainty related to the quantity of returns and process times respectively, via probability distributions and random variables. Fuzzy numbers is another common approach for describing uncertain data inputs via qualitative linguistic expression such as "high" or "low".

The inability of expressing and evaluating uncertainty within this type of decision can hinder the decision making process. Remanufacturing operates in a relatively high level of uncertainty, thus a degree of risk is attributed with each decision made. Understanding this risk is a key part of decision making. For businesses that operate in lower levels of uncertainty, such as an OEM remanufacturing a high volume of products, this is perhaps less of a concern, however for remanufacturers operating at high levels of uncertainty, such as independent remanufacturers, where less information regarding the products to be remanufactured is available, understanding uncertainty can be of greater importance. The inclusion of uncertainty to evaluate risk within a remanufacturing decision is another potential research area for expansion.

\subsection{Limitations}

Although a robust and transparent method has been used to develop this literature review the authors accept that a number of limitations exist within the study.

Defining the scope and drawing clear boundaries around the subject area proved to be a large challenge within the study due to the overlap with other similar research areas such as disassembly sequencing, remanufacturing production planning and other product EoL strategies such as recycling. Defining a clear boundary helps to keep the focus of the study concise and relevant. However, there will inadvertently be publications which lie outside this boundary that may have been of value. Within this study the authors decided to exclude publications focused upon the optimisation of production planning, inventory management, reverse logistics, disassembly sequencing and mathematical models designed to evaluate the effects of competition within remanufacturing.

As a framework for assessing the decision tools did not exist, the authors decided to develop one based upon existing literature and their experiences and meetings with industry. This framework, shown in section 2, is presented in the style of a narrative review. Due to time and resource constraints it has not been possible for the authors to analyse this material in the same systematic manner in which the review of the decision tools have been conducted. This acts as a limitation to the study as developed methodologies, such as grounded theorizing and content analysis, have not been used to analyse and determine the importance of the information, thus the findings must be treated as descriptive rather than as a formal theory. Instead, to minimise this limitation, authors have relied upon highly cited journal publications to ground the framework.

Finally limitations regarding the content analysis described in section 3 are discussed. The search method used in this study has been conducted in a systematic but rigid manner. Although this presents an explicit and transparent approach of searching for literature, it is possible that papers which are of value to this study were not found as they fall outside of the keyword search criteria or are not present within the databases used. Another limitation occurs during the review of the coded 
results as only a single person has been used. This reduces the validity of the content analysis as only using a single person may unintentionally bias results based upon their interpretations and preconceived ideas.

\section{Conclusion}

The key research objective of this study was to answer the question; What tools and methods that have been developed within academia to support the decision process of assessing and evaluating the viability of conducting remanufacturing, and how have they met the requirements of the decision stage. To answer this, a review of the literature regarding remanufacturing decision making was conducted and a framework was presented within section 2, highlighting decision factors, decision stages and challenges to decision making. A content analysis was then conducted to identify and then evaluate decision tools and methods. Using a systematic search process from three established bibliographic databases, 41 relevant publications were found. The publications were then evaluated against a set of decision requirements established within a framework of the problem in section 2 .

Economic factors were found to be the most widely used within the tools to assess remanufacturing. Environmental factors have received considerable attention, however social factors were often found to be neglected. Whilst tactical and strategic decision levels were well catered for, operational tools were found to be somewhat neglected. Perhaps the most significant finding of the study was the lack of uncertainty being considered within many of decision making tools. Uncertainty was identified as a key trait of remanufacturing and therefore decision tools need to take into account that often some the information which is necessary to make decisions will be unknown. Enabling tools to express uncertainty within input data and understand the risk associated with these decisions is an area for future research within these types of tools.

This study is the first that the authors are aware of, to both identify and evaluate decision support tools designed to evaluate the viability of remanufacturing, using a definitive set of requirements. It is hoped that findings from this study will assist researchers within this field with the development of future decision support applications for remanufacture.

\section{Acknowledgements}

This research was partly funded by the European Commission's FP7 project PREMANUS (http://www.premanus.eu/) under grant agreement 285541. The authors would like to additionally thank those companies interviewed for their time and help. 


\section{References}

Adler, D.P., Ludewig, P.A., Kumar, V., Sutherland, J.W., 2007. Comparing energy and other measures of environmental performance in the original manufacturing and remanufacturing of engine components

Anityasari, M., Han Bao, Kaebernick, H., 2005. Evaluation of product reusability based on a technical and economic model: a case study of televisions. Electronics and the Environment, 2005. Proceedings of the 2005 IEEE International Symposium on, 199-204

Anityasari, M., Kaebernick, H., 2008. A concept of reliability evaluation for reuse and remanufacturing. International Journal of Sustainable Manufacturing. 1-2, 3-17

Atasu, A., Sarvary, M., Van Wassenhove, L.N., 2008. Remanufacturing as a Marketing Strategy. MANAGEMENT SCIENCE. 10, 1731-1746

Ayres, R., Ferrer, G., Van Leynseele, T., 1997. Eco-efficiency, asset recovery and remanufacturing. European Management Journal. 5, 557-574

Barker, S., King, A., 2006. The development of a remanufacturing design platform model (RDPM): applying design platform principles to extend remanufacturing practice into new industrial sectors, 399-404

Behdad, S., Williams, A.S., Thurston, D., 2012. End-of-Life Decision Making With Uncertain Product Return Quantity. Journal of Mechanical Design. 10, 100902

Boehm, M., Thomas, O., 2013. Looking beyond the rim of one's teacup: a multidisciplinary literature review of Product-Service Systems in Information Systems, Business Management, and Engineering \& Design. J. Clean. Prod. 0, 245-260

Boustani, A., Sahni, S., Graves, S., Gutowski, T., 2010. Appliance remanufacturing and life cycle energy and economic savings, 1-6

Bras, B., McIntosh, M.W., 1999. Product, process, and organizational design for remanufacture - an overview of research. Robot. Comput. Integrated Manuf. 3, 167-178

Cao, H., Zhang, L., Liu, F., 2010. Deployment model for part reuse in customized design of remanufactured products. IET Conference Publications. 565 CP, 7-12

Daimon, T., Kondoh, S., Umeda, Y., 2003. Proposal of decision support method for life cycle strategy by estimating value and physical lifetimes. Environmentally Conscious Design and Inverse Manufacturing, 2003. EcoDesign '03. 2003 3rd International Symposium on, 109116

de Brito, M.P., van der Laan, E.A., 2009. Inventory control with product returns: The impact of imperfect information. Eur. J. Oper. Res. 1, 85-101

Dowlatshahi, S., 2005. A strategic framework for the design and implementation of remanufacturing operations in reverse logistics. Int J Prod Res. 16, 3455-3480 
Du, Y., Cao, H., Liu, F., Li, C., Chen, X., 2012. An integrated method for evaluating the remanufacturability of used machine tool. J. Clean. Prod. 1, 82-91

Dunmade, I., 2004. PLETS model: A sustainability concept based approach to product endof-life management, 118-126

Dyllick, T., Hockerts, K., 2002. Beyond the business case for corporate sustainability. Business Strategy and the Environment. 2, 130-141

Ferrer, G., Ketzenberg, M.E., 2004. Value of information in remanufacturing complex products. IIE Transactions. 3, 265-277

Galbreth, M.R., Blackburn, J.D., 2010. Optimal acquisition quantities in remanufacturing with condition uncertainty. Production and Operations Management. 1, 61-69

Gehin, A., Zwolinski, P., Brissaud, D., 2008. A tool to implement sustainable end-of-life strategies in the product development phase. J. Clean. Prod. 5, 566-576

Gerrard, J., Kandlikar, M., 2007. Is European end-of-life vehicle legislation living up to expectations? Assessing the impact of the ELV Directive on 'green' innovation and vehicle recovery. J. Clean. Prod. 1, 17-27

Ghazalli, Z., Murata, A., 2011. Development of an AHP-CBR evaluation system for remanufacturing: end-of-life selection strategy. International Journal of Sustainable Engineering. 1, 2-15

Goldey, C., Kuester, E., Mummert, R., Okrasinski, T., Olson, D., Schaeffer, W., 2010. Lifecycle assessment of the environmental benefits of remanufactured telecommunications product within a "green" supply chain, 1-6

Gonzalez, B., Adenso-Diaz, B., 2005. A bill of materials-based approach for end-of life decision making in design for the environment. International Journal of Production Research. 10, 2071-2099

Guide Jr,V.Daniel R., Van Wassenhove, L.N., 2009. The Evolution of Closed-Loop Supply Chain Research. Oper. Res. 1, 10-18

Guide, V.D.R., 2000. Production planning and control for remanufacturing: industry practice and research needs. J. Oper. Manage. 4, 467-483

Gutowski, T.G., Sahni, S., Boustani, A., Graves, S.C., 2011. - Remanufacturing and Energy Savings. - Environmental Science \& Technology. - 10, - 4540

Hatcher, G.D., Ijomah, W.L., Windmill, J.F.C., 2011. Design for remanufacture: a literature review and future research needs. J. Clean. Prod. 17-18, 2004-2014

Hubbard, G., 2009. Measuring organizational performance: beyond the triple bottom line. Business Strategy and the Environment. 3, 177-191 
Iberahim, F., Wahab, D.A., Nopiah, Z.M., Abdullah, S., 2011. Establishment of Remanufacturing Index for Locally Manufactured Automotive Components. Advanced Design and Manufacture Iv, 77-80

Ijomah, W.L., 2009. - Addressing decision making for remanufacturing operations and design-for-remanufacture. - International Journal of Sustainable Engineering. - 2, - 91

Ijomah, W.L., McMahon, C.A., Hammond, G.P., Newman, S.T., 2007. Development of design for remanufacturing guidelines to support sustainable manufacturing. Robot. Comput. Integrated Manuf. 6, 712-719

Ilgin, M.A., Gupta, S.M., 2011. Performance improvement potential of sensor embedded products in environmental supply chains. Resour. Conserv. Recycling. 6, 580-592

Ilgin, M.A., Gupta, S.M., 2010. Environmentally conscious manufacturing and product recovery (ECMPRO): A review of the state of the art. J. Environ. Manage. 3, 563-591

Inderfurth, K., Mukherjee, K., 2008. Decision support for spare parts acquisition in post product life cycle. Central European Journal of Operations Research. 1, 17-42

Inderfurth, K., 2005. Impact of uncertainties on recovery behavior in a remanufacturing environment: A numerical analysis. International Journal of Physical Distribution \& Logistics Management. 5, 318-336

Intlekofer, K., Bras, B., Ferguson, M., 2010. Energy implications of product leasing. Environ. Sci. Technol. 12, 4409-4415

Jun, H.-., Cusin, M., Kiritsis, D., Xirouchakis, P., 2007. A multi-objective evolutionary algorithm for EOL product recovery optimization: turbocharger case study. Int J Prod Res. $18-19,4573-4594$

Jun, H., Lee, D., Kim, J., Kiritsis, D., 2012. Heuristic algorithms for minimising total recovery cost of end-of-life products under quality constraints. Int J Prod Res. 19, 5330-5347

Kerr, W., Ryan, C., 2001. Eco-efficiency gains from remanufacturing: A case study of photocopier remanufacturing at Fuji Xerox Australia. J. Clean. Prod. 1, 75-81

King, A.M., Burgess, S.C., Ijomah, W., McMahon, C.A., 2006. Reducing waste: repair, recondition, remanufacture or recycle?. Sustainable Dev. 4, 257-267

Klausner, M., Grimm, W.M., Hendrickson, C., Horvath, A., 1998. Sensor-based data recording of use conditions for product takeback. Electronics and the Environment, 1998. ISEE-1998. Proceedings of the 1998 IEEE International Symposium on, 138-143

Krill, M., Thurston, D.L., 2005. Remanufacturing: Impacts of Sacrificial Cylinder Liners. J. Manuf. Sci. Eng. 3, 687-697

Kumar, V., Shirodkar, P.S., Camelio, J.A., Sutherland, J.W., 2007. Value flow characterization during product lifecycle to assist in recovery decisions. Int J Prod Res. 18$19,4555-4572$ 
Lee, H.B., Cho, N.W., Hong, Y.S., 2010. A hierarchical end-of-life decision model for determining the economic levels of remanufacturing and disassembly under environmental regulations. J. Clean. Prod. 13, 1276-1283

Li, D., Li, W., 2011. Technical Economic Analysis of Remanufacturing of Large-Scale Food Processing Equipments. Advanced Manufacturing Systems, Pts 1-3, 1033-1036

Lund, R.,T, 1985. Remanufacturing: The Experience of the United States and Implications for Developing Countries. World Bank Technical Paper

Lund, R.,T, 1984. Remanufacturing. Technology Review, 18-23

Matsumoto, M., Umeda, Y., 2011. An analysis of remanufacturing practices in Japan. Journal of Remanufacture

Mayyas, A., Qattawi, A., Omar, M., Shan, D., 2012. Design for sustainability in automotive industry: A comprehensive review. Renewable and Sustainable Energy Reviews. 4, 18451862

McKenna, R., Reith, S., Cail, S., Kessler, A., Fichtner, W., 2013. Energy savings through direct secondary reuse: an exemplary analysis of the German automotive sector. J. Clean. Prod. 0, 103-112

Michaud, M., Sroka, G.J., Benson, R.E., 2011. Refurbishing Wind Turbine Gears. Gear Solutions. 99, 28-39

Östlin, J., Sundin, E., Björkman, M., 2009. Product life-cycle implications for remanufacturing strategies. J. Clean. Prod. 11, 999-1009

Pandey, V., Thurston, D., 2010. Variability and Component Criticality in Component Reuse and Remanufacturing Systems. J. Comput. Inf. Sci. Eng. 4, 041004

Pandey, V., Thurston, D., 2010. Variability and Component Criticality in Component Reuse and Remanufacturing Systems. Journal of Computing and Information Science in Engineering. 4, 041004

Parkinson, H.J., Thompson, G., 2003. Analysis and taxonomy of remanufacturing industry practice. Proceedings of the Institution of Mechanical Engineers, Part E: Journal of Process Mechanical Engineering. 3, 243-256

Pochampally, K.K., Vadde, S., Kamarthi, S.V., Gupta, S.M., 2004. Beyond sensor-assisted diagnosis of used products. Environmentally Conscious Manufacturing Iv, 138-146

Pochampally, K.K., Gupta, S.M., 2012. Use of linear physical programming and Bayesian updating for design issues in reverse logistics. Int J Prod Res. 5, 1349-1359

PRé Consultants, 2000. Eco-indicator 99 Manual for Designers. July

Presley, A., Meade, L., Sarkis, J., 2007. A strategic sustainability justification methodology for organizational decisions: a reverse logistics illustration. Int J Prod Res. 18-19, 4595-4620 
Quariguasi-Frota-Neto, J., Bloemhof, J., 2012. An Analysis of the Eco-Efficiency of Remanufactured Personal Computers and Mobile Phones. Production and Operations Management. 1, 101-114

Rathore, P., Kota, S., Chakrabarti, A., 2011. Sustainability through remanufacturing in India: a case study on mobile handsets. J. Clean. Prod. 15, 1709-1722

Sarkis, J., 2003. A strategic decision framework for green supply chain management. J. Clean. Prod. 4, 397-409

Schau, E.M., Traverso, M., Lehmann, A., Finkbeiner, M., 2011. Life cycle costing in sustainability assessment — a case study of remanufactured alternators. Sustainability. 11, 2268-2288

Seitz, M.A., 2007. A critical assessment of motives for product recovery: the case of engine remanufacturing. J. Clean. Prod. 11-12, 1147-1157

Shrivastava, P., Zhang, H.C., Jianzhi Li, Whitely, A., 2005. Evaluating obsolete electronic products for disassembly, material recovery and environmental impact through a decision support system. Electronics and the Environment, 2005. Proceedings of the 2005 IEEE International Symposium on, 221-225

Smith, V.M., Keoleian, G.A., 2004. The Value of Remanufactured Engines: Life-Cycle Environmental and Economic Perspectives. J. Ind. Ecol. 1-2, 193-221

Spengler, T., Stolting, W., 2008. Life cycle costing for strategic evaluation of remanufacturing systems. Progress in Industrial Ecology, an International Journal. 1-2, 65-81

Subramoniam, R., Huisingh, D., Chinnam, R.B., 2010. Aftermarket remanufacturing strategic planning decision-making framework: theory \& practice. J. Clean. Prod. 16-17, 1575-1586

Subramoniam, R., Huisingh, D., Chinnam, R.B., 2009. Remanufacturing for the automotive aftermarket-strategic factors: literature review and future research needs. J. Clean. Prod. 13, 1163-1174

Subramoniam, R., Huisingh, D., Chinnam, R.B., Subramoniam, S., 2013. Remanufacturing Decision-Making Framework (RDMF): research validation using the analytical hierarchical process. J. Clean. Prod. 0, 212-220

Sundin, E., Lindahl, M., 2008. Rethinking product design for remanufacturing to facilitate integrated product service offerings. Electronics and the Environment, 2008. ISEE 2008. IEEE International Symposium on, 1-6

Sundin, E., Bras, B., 2005. Making functional sales environmentally and economically beneficial through product remanufacturing. J. Clean. Prod. 9, 913-925

Thierry, M.C., Salomon, M., Nunen, J.v., Wassenhove, L.v., 1995. Strategic issues in product recovery management. Calif. Manage. Rev. 2, 114-135 
Thomas Chen, Jun-Nan Wu, 2003. Neural network model for product end-of-life strategies. Electronics and the Environment, 2003. IEEE International Symposium on, 159-164

Walsh, B., 2010. PSS for Product Life Extension through Remanufacturing, 261-268

Wang, Q., Li, C., 2011. Risk Assessment for Remanufacturing System Based on Neural Network. Advanced Materials Research, 1382-1385

Wang, W., Tseng, M.M., 2010. Economic analysis of product end-of-life strategies to achieve design for sustainable manufacturing. IET Conference Publications. 565 CP, 268-272

Xanthopoulos, A., Iakovou, E., 2009. On the optimal design of the disassembly and recovery processes. Waste Manage. 5, 1702-1711

Xing, K., Belusko, M., Luong, L., Abhary, K., 2007. An evaluation model of product upgradeability for remanufacture. The International Journal of Advanced Manufacturing Technology. 1, 1-14

Xing, K., Luong, L., 2009. Modelling and evaluation of product fitness for service life extension. J. Eng. Des. 3, 243-263

Yang, M., Chen, M., 2005. Life cycle of remanufactured engines. J. Cent. South Univ. Technol., 81-85

Zhang, H.C., Li, J., Shrivastava, P., Whitley, A., Merchant, M.E., 2004. A WEB-BASED SYSTEM FOR REVERSE MANUFACTURING AND PRODUCT ENVIRONMENTAL IMPACT ASSESSMENT CONSIDERING END-OF-LIFE DISPOSITIONS. CIRP Ann. Manuf. Technol. 1, 5-8

Zhou, J., Huang, P., Zhu, Y., Deng, J., 2012. A quality evaluation model of reuse parts and its management system development for end-of-life wheel loaders. J. Clean. Prod. 0, 239-249 